Article

\title{
Promotion of Ca-Co Bifunctional Catalyst/Sorbent with Yttrium for Hydrogen Production in Modified Chemical Looping Steam Methane Reforming Process
}

\author{
Samira Akbari-Emadabadi, Mohammad Reza Rahimpour *, Ali Hafizi and Peyman Keshavarz \\ Department of Chemical Engineering, Shiraz University, Shiraz 71345, Iran; \\ samiraakbari_88@yahoo.com (S.A.-E.); hafizi@shirazu.ac.ir (A.H.); pkeshavarz@shirazu.ac.ir (P.K.) \\ * Correspondence: rahimpor@shirazu.ac.ir
}

Received: 6 June 2017; Accepted: 17 August 2017; Published: 13 September 2017

\begin{abstract}
In this study, the application of a calcium-based bifunctional catalyst/sorbent is investigated in modified chemical looping steam methane reforming (CLSMR) process for in situ $\mathrm{CO}_{2}$ sorption and $\mathrm{H}_{2}$ production. The yttrium promoted $\mathrm{Ca}-\mathrm{Co}$ samples were synthesized and applied as bifunctional catalysts/sorbent. The influence of reduction temperature $\left(500-750{ }^{\circ} \mathrm{C}\right), \mathrm{Ca} / \mathrm{Co}$ and $\mathrm{Ca} / \mathrm{Y}$ ratios (1.5- $\infty$ and 3-18, respectively) and catalyst life time are determined in CLSMR process. The physicochemical transformation of fresh, used and regenerated samples after 16 redox cycles are determined using $\mathrm{X}$-ray powder diffraction $(\mathrm{XRD}), \mathrm{N}_{2}$ adsorption-desorption, field emission scanning electron microscopy (FESEM), energy dispersive X-ray spectroscopy (EDX) and transmission electron microscopy (TEM) techniques. The effect of yttrium promoter on the structure of catalyst and regeneration step on the reversibility of bifunctional catalyst/sorbent was two important factors. The characterization results revealed that the presence of yttrium in the structure of Ca-9Co sample could improve the morphology and textural properties of catalyst/sorbents. The suitable reversibility of bifunctional catalyst/sorbents during the repeated cycles is confirmed by characterization of calcined samples. The Ca-9Co-4.5Y as optimal catalyst illustrated superior performance and stability. It showed about $95.8 \%$ methane conversion and $82.9 \%$ hydrogen yield at $700{ }^{\circ} \mathrm{C}$ and stable activity during 16 redox cycles.
\end{abstract}

Keywords: bifunctional catalyst/sorbent; $\mathrm{H}_{2}$ production; $\mathrm{CO}_{2}$ sorption; methane reforming; chemical looping reforming

\section{Introduction}

Excessive consumption of fossil fuels (natural gas, coal and oil) and emission of large amount of greenhouse gases such as $\mathrm{CO}_{2}$ have an uncontrollable impact on global warming. This matter has increased worldwide environmental concern [1-4]. Further improvements in the efficiency of energy production processes and the use of environmental friendly energy carriers are effective methods to overcome these problems $[5,6]$. Hydrogen is introduced as a good candidate to achieve this goal. $\mathrm{H}_{2}$ has been considered as a potential alternative fuel that can provide the future energy. It is also a clean energy source owing to its by-product that is harmless water vapor when it is converted into useful energy [7-10]. Hydrogen could be used as an important feedstock in different chemical and petrochemical processes such as methanol, ammonia and hydrochloric acid production. In addition, it is a suitable fuel for fuel cells, turbines and internal combustion engines [7,11-15]. In recent years, production of hydrogen could be performed by various processes such as electrolysis, biomass gasification and reforming [5,16-20]. However, reforming of natural gas is a common industrial technology for large scale of hydrogen production. Methane has received particular attention due to its high availability and low cost. In addition, it has high hydrogen to carbon ratio and produces fewer 
by-products compared to other hydrocarbons $[12,17,21]$. According to steam methane reforming (SMR) or partial oxidation of methane (POM) processes, methane was initially reacted with steam or oxygen to produce synthesis gas in the reformer (Equation (1) for SMR and Equation (2) for POM) [22]. Then, water gas shift (WGS) reaction was applied to increase the molar ratio of $\mathrm{H}_{2} / \mathrm{CO}$ for the production of hydrogen.

$$
\begin{aligned}
& \mathrm{CH}_{4}+\mathrm{H}_{2} \mathrm{O} \leftrightarrow 3 \mathrm{H}_{2}+\mathrm{CO} \Delta \mathrm{H}_{298 \mathrm{~K}}=206 \frac{\mathrm{kJ}}{\mathrm{mol}} \\
& \mathrm{CH}_{4}+\frac{1}{2} \mathrm{O}_{2} \leftrightarrow 2 \mathrm{H}_{2}+\mathrm{CO} \Delta \mathrm{H}_{298 \mathrm{~K}}=-35 \frac{\mathrm{kJ}}{\mathrm{mol}} \\
& \mathrm{CO}+\mathrm{H}_{2} \mathrm{O} \leftrightarrow \mathrm{H}_{2}+\mathrm{CO}_{2} \Delta \mathrm{H}_{298 \mathrm{~K}}=-41 \frac{\mathrm{kJ}}{\mathrm{mol}}
\end{aligned}
$$

$\mathrm{H}_{2}$ production in Reforming process has some problems such as difficult reaction condition, high energy consumption, multiple steps and high process costs $[17,23]$. In addition, in partial oxidation of methane, the $\mathrm{O}_{2}$ comes from either air or pure oxygen [24]. Using air as oxygen source has the disadvantage of $\mathrm{N}_{2}$ impurity and $\mathrm{NO}_{\mathrm{X}}$ in its syngas, while a costly oxygen plant is required in the second one [25].

In order to overcome these defects, chemical looping reforming (CLR) concept has been defined in recent years. In this method, a metal oxide as solid oxygen carrier (OC) is used instead of air for reduction of fuel to synthesis gas $\left(\mathrm{H}_{2}\right.$ and $\left.\mathrm{CO}\right)$. As a result, the fuel and air do not contact directly. The oxygen will be transferred from OC to fuel through the reduction of metal oxide to $\mathrm{Me}_{\mathrm{x}} \mathrm{O}_{\mathrm{y}-1}$, according to Equation (4). Subsequently, the reduced metal oxide is reoxidized to its initial state $\left(\mathrm{Me}_{\mathrm{x}} \mathrm{O}_{\mathrm{y}}\right)$ as indicated in Equation (5) [5,26].

$$
\begin{gathered}
\mathrm{Me}_{\mathrm{x}} \mathrm{O}_{\mathrm{y}}+\mathrm{CH}_{4} \leftrightarrow \mathrm{Me}_{\mathrm{x}} \mathrm{O}_{\mathrm{y}-1}+\mathrm{CO}+\mathrm{H}_{2} \\
\mathrm{Me}_{\mathrm{x}} \mathrm{O}_{\mathrm{y}-1}+\frac{1}{2} \mathrm{O}_{2} \leftrightarrow \mathrm{Me}_{\mathrm{x}} \mathrm{O}_{\mathrm{y}}
\end{gathered}
$$

According to Equation (3), an elimination product is necessary for the complete conversion of $\mathrm{CO}$ to $\mathrm{CO}_{2}$ and producing high purity hydrogen. If a product of WGSR were removed during the process, the equilibrium would be shifted to the right and the amount of produced hydrogen increases (Le Chatelier's principle). The use of hydrogen membranes (for eliminating hydrogen) and carbon dioxide sorbents (for removing $\mathrm{CO}_{2}$ from the gaseous products) are two effective methods for achieving this purpose. Therefore, the $\mathrm{CO}_{2}$ sorption process can be used along with the chemical looping steam methane reforming process and introduce a new concept, which is so-called sorption enhanced chemical looping reforming (SECLR) [27]. Ca-, Mg- and Li-based solid sorbents are highly impressive sorbents in $\mathrm{CO}_{2}$ sorption process. However, Ca-based sorbents are more interesting because of its high $\mathrm{CO}_{2}$ sorption capacity $\left(0.786 \mathrm{~g}\right.$ of $\mathrm{CO}_{2} / \mathrm{g}$ of sorbent), resistivity of coke rein, stability in long term cyclic operation, low cost and wide availability [28-31]. The exothermic carbonation reaction between calcium oxide and $\mathrm{CO}_{2}$ is performed as shown in Equation (6).

$$
\mathrm{CaO}_{(\mathrm{s})}+\mathrm{CO}_{2(\mathrm{~g})} \rightarrow \mathrm{CaCO}_{3(\mathrm{~s})} \Delta \mathrm{H}_{298 \mathrm{~K}}=-178 \frac{\mathrm{kJ}}{\mathrm{mol}}
$$

The calcination of $\mathrm{CaCO}_{3}$ is required for regeneration of sorbent and reusing $\mathrm{CaO}$ in multiple reforming cycles (Equation (7)).

$$
\mathrm{CaCO}_{3(\mathrm{~s})} \rightarrow \mathrm{CaO}_{(\mathrm{s})}+\mathrm{CO}_{2(\mathrm{~g})} \Delta \mathrm{H}_{298 \mathrm{~K}}=178 \frac{\mathrm{kJ}}{\mathrm{mol}}
$$

Researchers have more recently examined the uses of physical mixture of calcium oxide and an oxygen carrier in the SER process. In this regard, Hafizi and his co-workers $[12,18]$ synthesized $15 \mathrm{Fe}-5 \mathrm{Ca} / \mathrm{Al}_{2} \mathrm{O}_{3}$ and $22 \mathrm{Fe}_{2} \mathrm{O}_{3} / \mathrm{MgAl}_{2} \mathrm{O}_{4}$ oxygen carriers and cerium promoted $\mathrm{CaO}$ sorbent. In their 
studies, OCs and sorbents were mixed and used in SECLR process to produce hydrogen with high purity. Buelens et al. [32] considered Ni/ $\mathrm{MgAl}_{2} \mathrm{O}_{4}$ as methane reforming catalyst, active $\mathrm{Fe}_{2} \mathrm{O}_{3}$ particles supported in a matrix of $\mathrm{MgAl}_{2} \mathrm{O}_{4}$ particles as oxygen carrier and $\mathrm{CaO}$ promoted by $\mathrm{Al}_{2} \mathrm{O}_{3}$ as solid $\mathrm{CO}_{2}$ sorbent in SDRM process for producing high purity syngas. Dou et al. [33] studied $\mathrm{NiO} / \mathrm{NiAl}_{2} \mathrm{O}_{4}$ oxygen carrier and a solid sorbent such as calcium oxide in SECLR of glycerol. Ryden and Ramos [34] developed $\mathrm{NiO}$ oxygen carrier and calcium based $\mathrm{CO}_{2}$ sorbent in SECLR of methane. These studies showed that calcium was an effective agent for enhancing the purity of hydrogen. The evidence indicates that calcium oxide a long with an oxygen carrier as bifunctional catalyst/sorbent could be used in chemical looping processes. Figure 1 illustrates the overall mechanism of SECLR process that consists of three interconnected reactors. In the first reactor, oxygen carrier is reduced during the reaction with methane (Equation (4)), while bifunctional catalyst/sorbent simultaneously performs a direct reaction with methane in the presence of steam for the production of hydrogen rich gas stream (Equation (8)). When some reactions including methane reforming, $\mathrm{CO}_{2}$ sorption and water gas shift reaction occur at the same time, the overall procedure leads to the following reaction:

$$
2 \mathrm{CH}_{4(\mathrm{~g})}+4 \mathrm{H}_{2} \mathrm{O}_{(\mathrm{g})}+\mathrm{CaO}_{(\mathrm{s})} \leftrightarrow \mathrm{CaCO}_{3(\mathrm{~s})}+8 \mathrm{H}_{2(\mathrm{~g})}+\mathrm{CO}_{2} \Delta \mathrm{H}_{298 \mathrm{~K}}=151 \frac{\mathrm{kJ}}{\mathrm{mol}}
$$

In this reaction, calcium oxide is transformed to calcium carbonate and thus a calcination step is required for returning to its initial state. The calcination of calcium carbonate is performed at high temperature in the second reactor owing to the endothermic nature of the regeneration reaction (Equation (7)). The third reactor is applied in order to reoxidize the reduced oxygen carrier $[27,35]$.

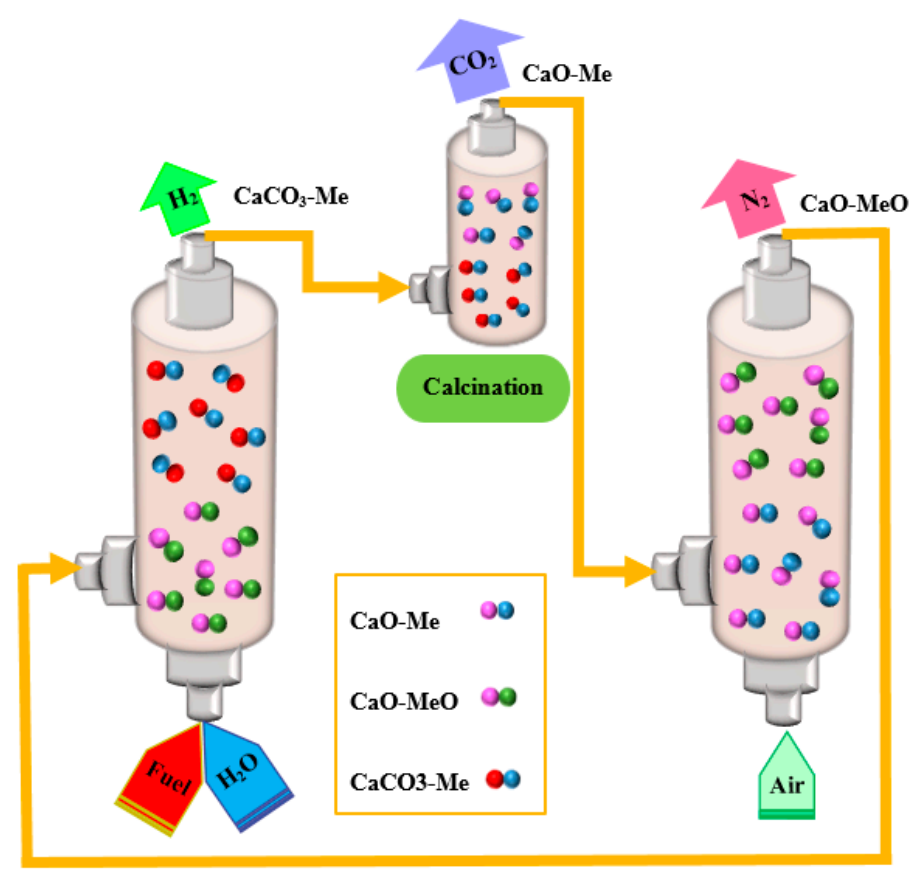

Figure 1. Conceptual scheme of modified chemical looping steam methane reforming process.

As stated above, for improving the activity of catalyst in CLR process, the addition of an appropriate oxygen carrier to the structure of calcium oxide seems to be necessary. The required oxygen carrier should be able to undergo repeated redox cycles. Furthermore, some important screening criteria such as high methane conversion, low cost, an acceptable oxygen transfer capacity, attrition and agglomeration resistance, non-toxicity and sufficient reversibility should be considered for a correct choice $[36,37]$. Some possible transition metals including active oxides of nickel, copper, cobalt, iron and manganese, possess greatly conditions mentioned above [36,38]. These metals have high 
tendency to deposition: not enough reactivity of iron and manganese, high tendency to agglomeration and sintering at high temperature for copper owing to its low melting point, high speed of carbon formation on the surface of oxygen carrier and subsequently rapid catalyst deactivation for nickel. Cobalt has a high oxygen storage capacity and a suitable activity in reaction with methane. In addition, only a few studies on the application of cobalt oxide as oxygen carrier are reported in the CLSMR process [9,39-41].

On the other hand, the use of appropriate promoter in the structure of bifunctional catalyst/ sorbent is an effective technique for the modifications of the textural and catalytic properties. In such cases, promoters could suppress the coke formation and prevent sintering and agglomeration of the samples [42]. Among different promoters, yttrium possesses specific properties which differ it from other promoters. Ramirez-Hernandez et al. [43] investigated the influence of yttrium promote $\mathrm{Ni} / \mathrm{Al}_{2} \mathrm{O}_{3}$ in the steam reforming of ethanol. Their results illustrated that the presence of yttrium caused less carbon deposition, better reducibility of nickel and lower temperature. $\mathrm{Li}$ and the co-workers [44] assessed the promoting behavior of yttrium over NiO/SBA-15 catalyst in the $\mathrm{CO}_{2}$ reforming of methane and found that it has decreasing effect on the carbon deposition and increased the dispersion of nickel, thermal stability and catalytic activity. Therefore, yttrium seems to be potentially appropriate for applying in our favorable process.

The main objective of this research is the investigation of a novel bifunctional catalyst/sorbent in the modified configuration of chemical looping steam methane reforming process for one step production of hydrogen rich stream. For this purpose, yttrium is incorporated in the framework of calcium-cobalt using co-precipitation method and used as bifunctional catalyst/sorbent. Different parameters such as the effect of reduction temperature, calcium to cobalt and calcium to yttrium mass ratios and cyclic life time are studied on the performance of catalysts. The evaluation of gas composition provided a useful technique for understanding the performance of bifunctional catalyst/sorbent and modified process. Moreover, various characterization techniques include: XRD, Brunauer-Emmett-Teller (BET), EDX, TEM and FESEM are applied to analyze the fresh and used (in both the calcined and carbonated forms) samples. Finally, the life time and stability of optimized catalyst are investigated over 16 redox cycles.

\section{Results and Discussion}

\subsection{Sample Characterization}

The freshly synthesized samples were characterized before activity tests, after reduction period and after calcination/oxidation section to investigate the structural changes of each catalyst/sorbent. The XRD patterns of fresh, used and regenerated $\mathrm{Ca}-9 \mathrm{Co}$ and $\mathrm{Ca}-9 \mathrm{Co}-4.5 \mathrm{Y}$ bifunctional samples after 16 redox cycles are demonstrated in Figure 2. The used samples were in the reactor during 16 cycles within about $26 \mathrm{~h}$. The regenerated samples had the same procedure with a different step at the end, about $1 \mathrm{~h}$ the calcination/oxidation was carried out on the samples. The patterns of both fresh samples shows the formation of $\mathrm{CaO}$ at $2 \theta=32.3^{\circ}, 37.5^{\circ}, 54.0^{\circ}, 79.9^{\circ}$ and $88.8^{\circ}$ (JCPDS card No. 01-082-1691). The results of used samples show the formation of $\mathrm{CaCO}_{3}$ according to $2 \theta=23.1^{\circ}, 29.5^{\circ}, 43.3^{\circ}, 47.3^{\circ}$, $48.6^{\circ}$ and $57.5^{\circ}$ (JCPDS card No. 00-002-0629). The XRD patterns of calcined samples have expressed that calcium carbonates are completely converted to calcium oxide and can be considered as the main substance. It shows appropriate reversibility of calcium oxide through multiple cycles. A comparison between used samples after 16 redox cycles demonstrates that the sample containing yttrium showed better performance in direct reaction with methane. The intensity of unreacted $\mathrm{CaO}$ peaks after reduction step is decreased severely in the case of yttrium promoted bifunctional catalyst/sorbent. As presented in this figure, the calcium-cobalt spinel $\left(\mathrm{Ca}_{2} \mathrm{Co}_{2} \mathrm{O}_{5}\right)$ is detected at $2 \theta=16.5^{\circ}$ and $39.5^{\circ}$ in Ca-9Co sample, while it is clear that calcium-cobalt spinel does not exist in Ca-9Co-4.5Y sample. It proves that yttrium promoter is able to properly inhibit the formation of calcium-cobalt spinel. This phenomenon shows that yttrium as structural promoter could significantly increase the stability and 
activity of catalyst/sorbents [36]. In Figure 2, it should be noted that the elemental carbon (C) was not observed over the used samples. Therefore, it could be found that carbon deposition did not occur on the surface of bifunctional catalyst/sorbents, which could be due to the basic and natural properties of calcium oxide and yttrium promoter. On the other hand, the cobalt oxide $\left(\mathrm{Co}_{3} \mathrm{O}_{4}\right)$ in fresh sample is reduced to $\mathrm{CoO}$ after reduction period, while it is reoxidized to $\mathrm{Co}_{3} \mathrm{O}_{4}$ after calcination/oxidation step. The reduction of $\mathrm{Co}_{3} \mathrm{O}_{4}$ in the first cycle shows the transference of lattice oxygen (from cobalt oxide as oxygen carrier) to methane.
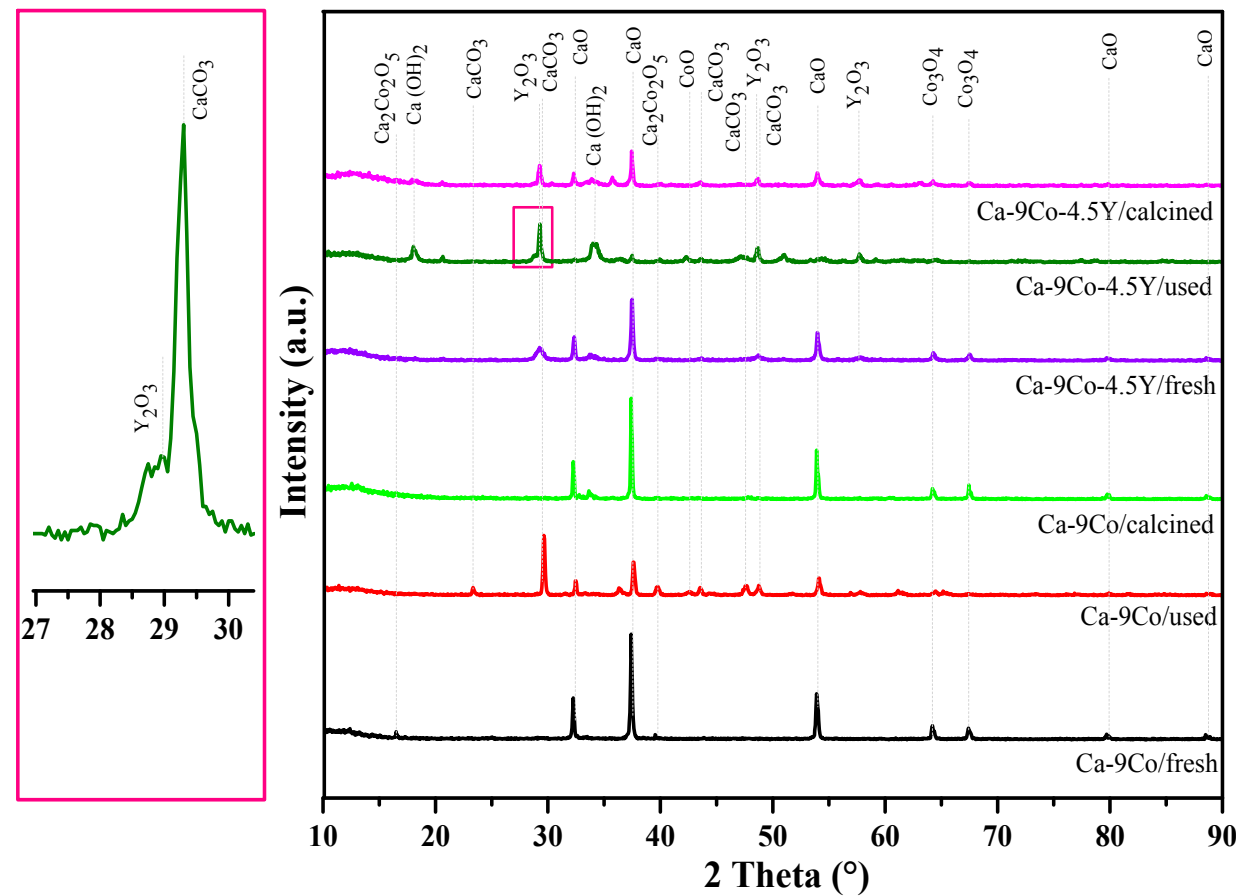

Figure 2. XRD patterns of fresh, used $\left(\right.$ at $700{ }^{\circ} \mathrm{C}$ ) and regenerated (calcined) catalyst/sorbents after 16 redox cycles.

Figure 3 illustrates the FESEM images of fresh samples including synthesized calcium, Ca-9Co and Ca-9Co-4.5Y. As shown in Figure 3b the Ca-9Co catalyst has a dense structure with more aggregated particles. To investigate the influence of cobalt on the surface properties of catalyst/sorbent, FESEM images of pure calcium oxide is demonstrated (Figure 3a). It is clear in this figure that the particle size of synthesized calcium oxide is increased by adding cobalt as oxygen carrier to the structure of catalyst/sorbent (Figure 3a,b). It could be stated that cobalt brings the small particles of calcium oxide close together and makes larger particles than synthesized pure calcium. It explains that cobalt compresses the structure of calcium oxide. It is expected that using a suitable structural promoter in the framework of catalyst/sorbent can solve this problem. A comparison between Ca-9Co and Ca-9Co-4.5Y samples (Figure 3b,c) indicates that the particle size of Ca-9Co-4.5Y is smaller than that of Ca-9Co. It shows that yttrium can decrease the size of calcium oxide particles and create a more uniform structure. 

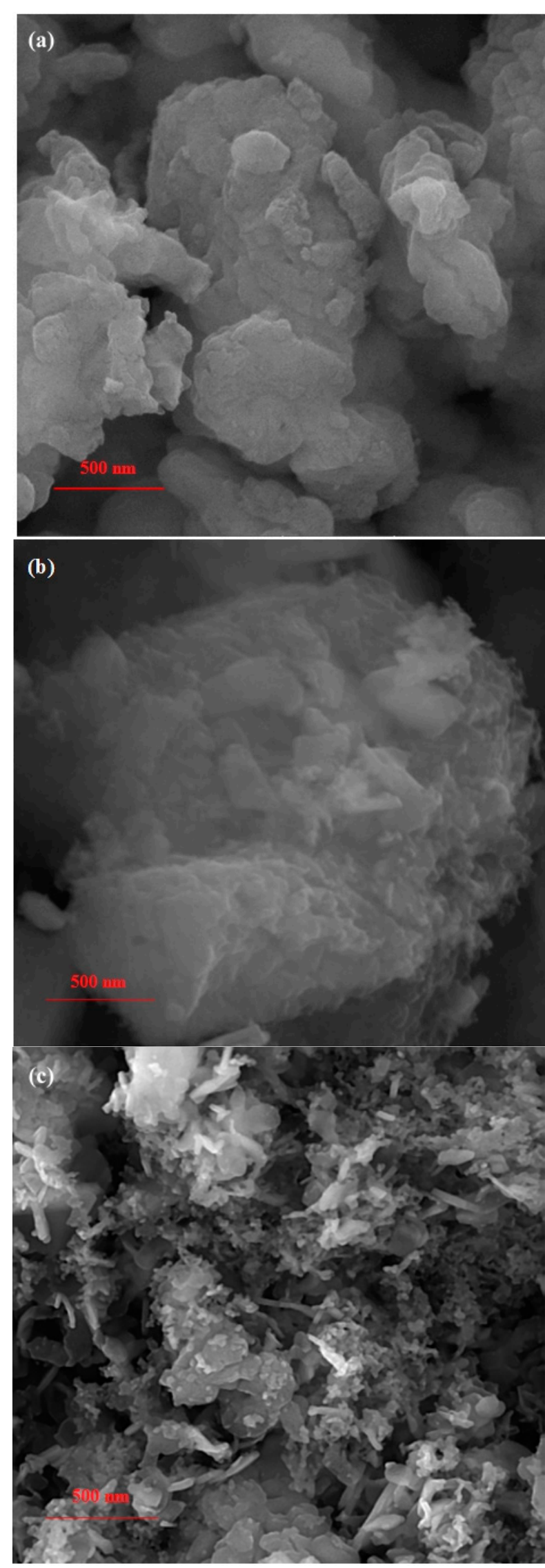

Figure 3. FESEM images of fresh: (a) synthesized calcium; and (b) Ca-9Co; and (c) Ca-9Co-4.5Y catalyst/sorbents. 
Figure 4 indicates the nitrogen adsorption/desorption isotherms of fresh Ca-9Co and Ca-9Co-4.5Y samples. Both catalyst/sorbents exhibited II-type isotherms and H3-type hysteresis loops. This isotherm shows that the samples are macro porous and the specified hysteresis loops indicate the monolayer adsorption of $\mathrm{N}_{2}$ on the surface of catalysts [45]. The pore size distribution of Ca-9Co reveals that the pores are distributed over a wide range $(5-120 \mathrm{~nm})$, while the addition of yttrium could arrange the pores in a narrow range $(20-85 \mathrm{~nm})$.

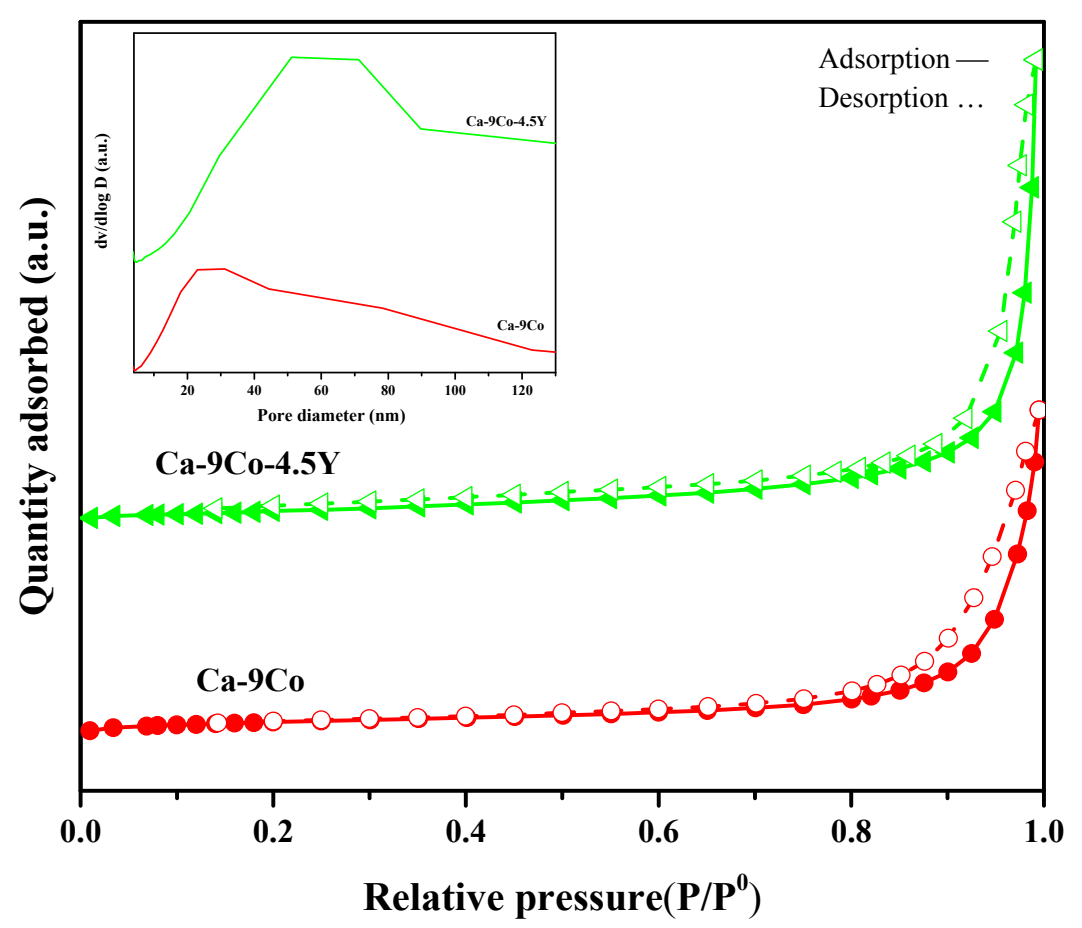

Figure 4. $\mathrm{N}_{2}$ adsorption/desorption isotherms and pore size distributions of fresh samples.

The physical properties of fresh Ca-9Co and Ca-9Co-4.5Y catalyst/sorbents including BET surface area, average pore diameter and pore volume are reported in Table 1. As indicated in this table, the BET surface area and pore volume of Ca-9Co sample were increased by adding yttrium as promoter to the structure of sample, while no noticeable change was observed in average pore diameter. It shows that yttrium enhances the porosity and uniformity of catalyst/sorbent.

Table 1. Structural properties of the fresh catalyst/sorbents.

\begin{tabular}{|c|c|c|c|}
\hline Sample & BET Surface Area $\left(\mathrm{m}^{2} / \mathrm{g}\right)$ & Pore Diameter $(\mathrm{nm})^{a}$ & Pore Volume $\left(\mathrm{cm}^{3} / \mathrm{g}\right)^{b}$ \\
\hline Ca-9Co/fresh & 14.0 & 25.55 & 0.111 \\
\hline Ca-9Co-4.5Y/fresh & 17.9 & 26.41 & 0.161 \\
\hline
\end{tabular}

${ }^{\mathrm{a}} \mathrm{BJH}$ desorption average pore diameter. ${ }^{\mathrm{b}} \mathrm{BJH}$ desorption pore volume.

The TEM analysis of fresh samples was performed to compare the agglomeration and dispersion of metal oxide particles in the presence of yttrium promoter. Figure 5 displays the TEM images of Ca-9Co and $\mathrm{Ca}-9 \mathrm{Co}-2 \mathrm{Y}$ bifunctional catalyst/sorbents. The agglomeration of cobalt-calcium matrix particles is observed in some parts of Ca-9Co sample as shown in Figure 5a. However, yttrium improved the dispersion of cobalt oxide particles and decreased the particle size (Figure $5 b$ ). In addition, these images clearly illustrate the porous structure of fresh samples. 


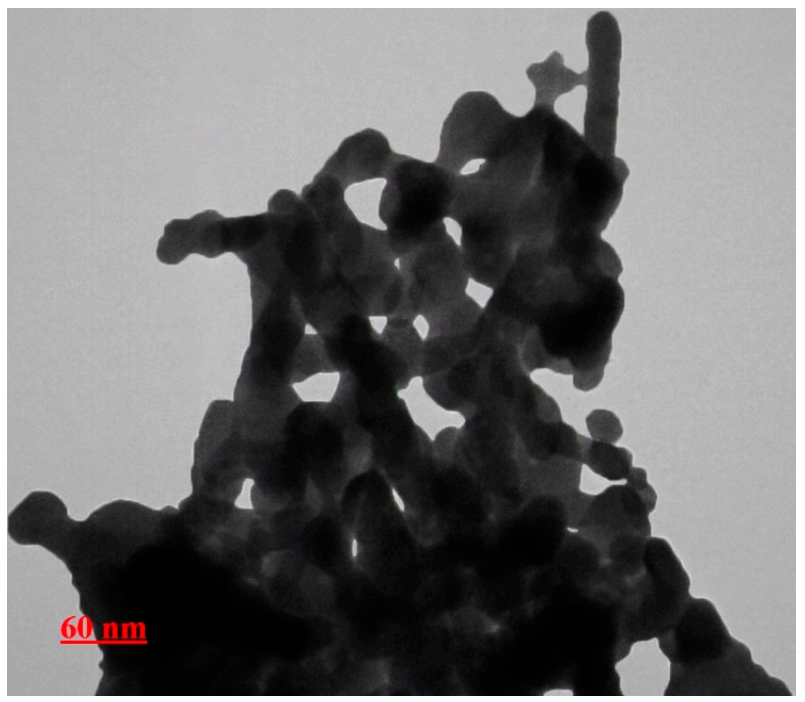

(a)

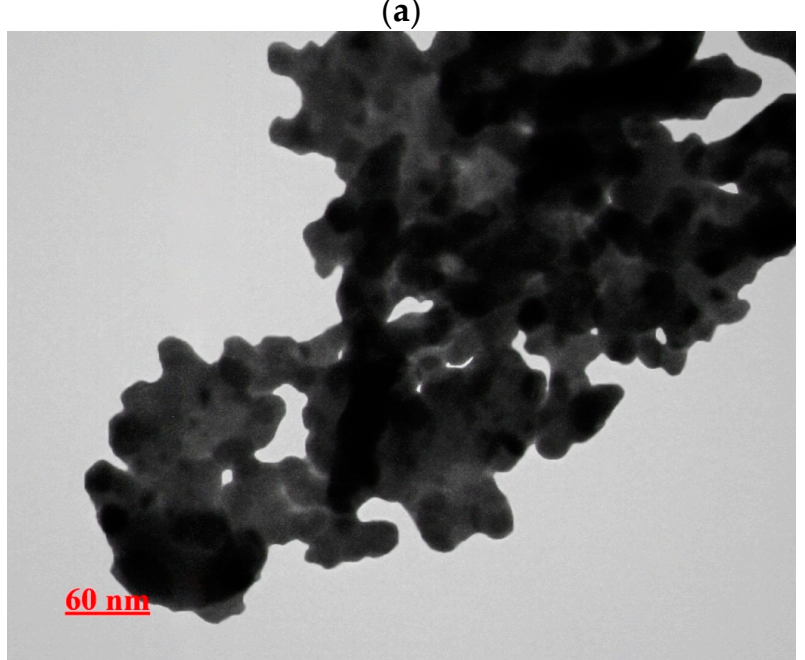

(b)

Figure 5. TEM images of fresh: (a) Ca-9Co; and (b) Ca-9Co-4.5Y.

\subsection{Catalytic Activity of $\mathrm{Ca}-m \mathrm{Co}$}

To achieve the optimal cobalt loading, Ca-mCo $(\mathrm{m}=1.5,2.3,4.0,9.0$ and $\infty)$ bifunctional catalyst/sorbents were prepared and tested in CLSMR process. According to these examinations, the methane conversion, hydrogen yield and average $\mathrm{H}_{2} / \mathrm{CO}$ molar ratio over Ca-mCo catalysts were determined as shown in Figure 6. The tests are performed at different reduction temperatures $\left(500-750{ }^{\circ} \mathrm{C}\right)$ and calcination/oxidation at $750{ }^{\circ} \mathrm{C}$. For instance, a 100-min reduction cycle is performed at $550{ }^{\circ} \mathrm{C}(0-50 \mathrm{~min})$ followed by calcination/oxidation at $750{ }^{\circ} \mathrm{C}(50-100 \mathrm{~min})$. The molar ratio of steam to carbon is considered constant and equal to 2 , which is needed in the reduction step. This figure shows that methane conversion and hydrogen yield are increased with reduction temperature, which is because of the endothermic nature of direct reaction between methane and bifunctional catalyst/sorbent (Equation (7)). In addition, Figure 6 reveals that the methane conversion and hydrogen yield are increased to about $94.9 \%$ and $81.5 \%$ with the increment of calcium to cobalt mass ratio and then decreased with further increasing the ratio. In addition, average $\mathrm{H}_{2} / \mathrm{CO}$ molar ratio follows a similar trend and it is enhanced to about 5.2 for Ca-9Co at $700{ }^{\circ} \mathrm{C}$ and then decreases to about 4.8 for $\mathrm{Ca}-\infty \mathrm{Co}$ at the same temperature. It should be noted that the addition of cobalt as a suitable oxygen carrier to the structure of catalyst increases the activity; however, cobalt compacts the structure 
of catalyst and greater amounts of cobalt can prevent the easier accessibility of gaseous reactant to inner layers of catalyst/sorbent, which confirms the BET results. Therefore, it could be found that maximum methane conversion, hydrogen yield and average $\mathrm{H}_{2} / \mathrm{CO}$ molar ratio occur using the bifunctional catalyst/sorbent with the $\mathrm{Ca} / \mathrm{Co}$ mass ratio of 9 (Ca-9Co). For example, the average methane conversion and average hydrogen yield are increased from $72.6 \%$ and $65.4 \%$ for Ca- $1.5 \mathrm{Co}$ to $94.9 \%$ and $81.5 \%$ for Ca- $9 \mathrm{Co}$ at $700{ }^{\circ} \mathrm{C}$, respectively. The average methane conversion of Ca-9Co is about $93.15 \%$ at $650{ }^{\circ} \mathrm{C}$.
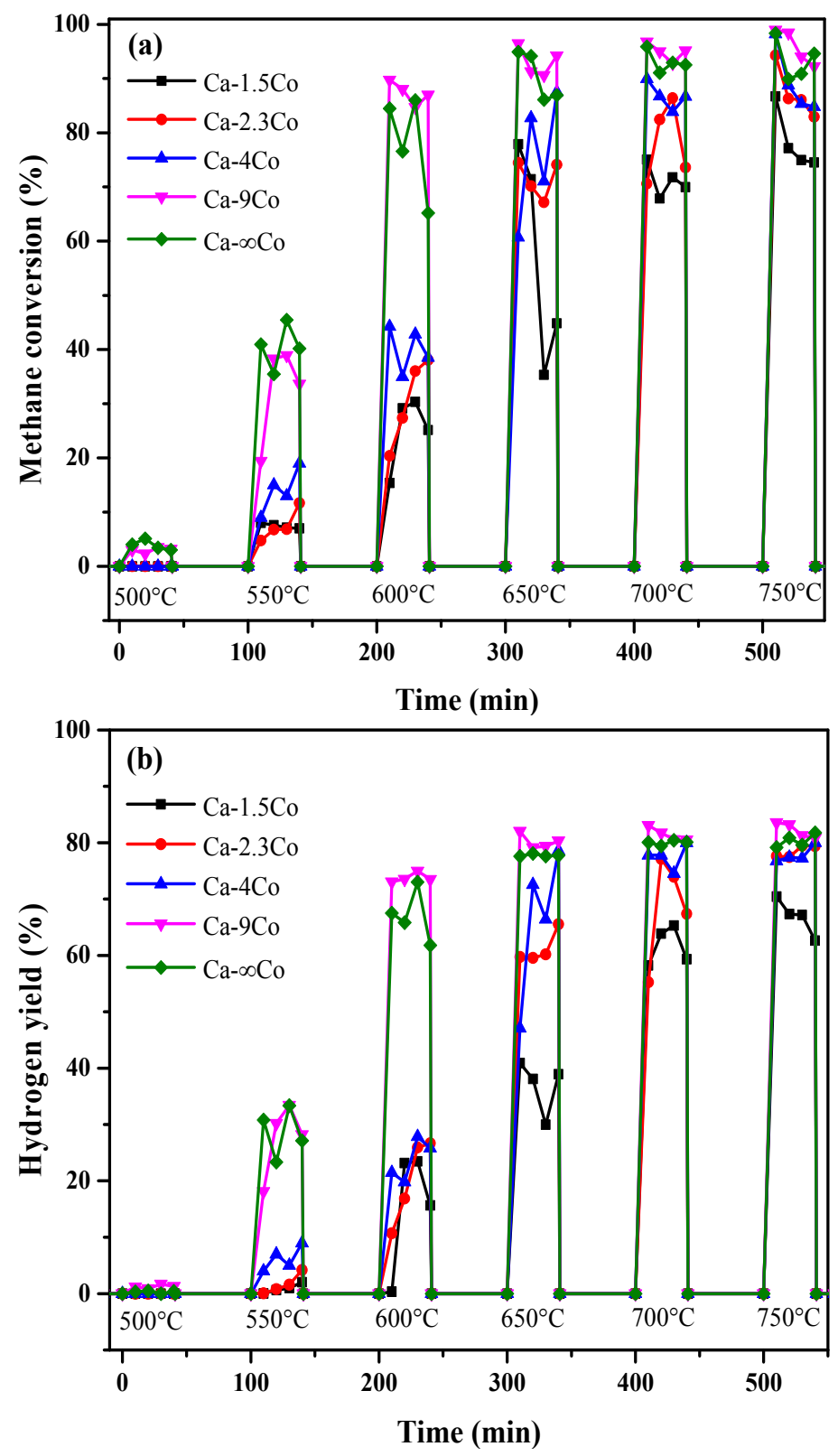

Figure 6. Cont. 


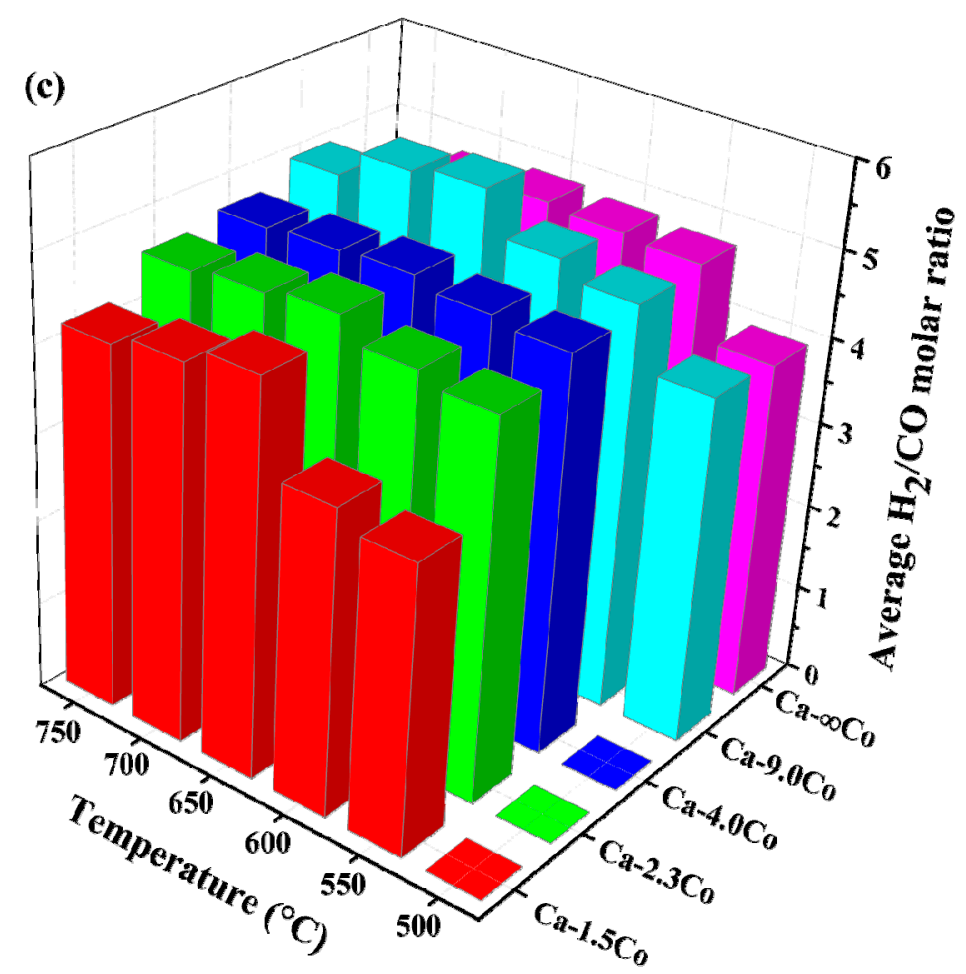

Figure 6. Effect of reaction temperature and calcium to cobalt mass ratio on: (a) methane conversion; (b) hydrogen yield; and (c) average $\mathrm{H}_{2} / \mathrm{CO}$ molar ratio, at $\mathrm{S} / \mathrm{C}=2$.

\subsection{Effect of Yttrium Promoter on Catalytic Activity of Ca-9Co-nY Catalyst/Sorbent}

To study the effect of yttrium promoter on the structural properties and activity of Ca-Co bifunctional catalyst/sorbent, Ca-9Co-nY samples with different calcium to yttrium mass ratios ( $\mathrm{n}=3.0,4.5,9.0,18.0)$ were synthesized and examined in CLSMR process at different reduction temperatures (Figure 7). It shows that raising the reduction temperature increases methane conversion and hydrogen yield for all samples. For instance, methane conversion and hydrogen yield are about $20.9 \%$ and $15.0 \%$ at $500{ }^{\circ} \mathrm{C}$ and reach to about $96.9 \%$ and $83.4 \%$ at $750{ }^{\circ} \mathrm{C}$ for Ca- $9 \mathrm{Co}-3 \mathrm{Y}$, respectively. As indicated in Figure 7c, by decreasing the calcium to yttrium mass ratio from 18 to 4.5, the average $\mathrm{H}_{2} / \mathrm{CO}$ molar ratio is increased from about 4.5 to 5.3 at $700{ }^{\circ} \mathrm{C}$. The average $\mathrm{H}_{2} / \mathrm{CO}$ molar ratio was decreased slightly by further increment of yttrium content. It shows that the addition of yttrium content increases the porosity of catalyst/sorbent and improves the dispersion of cobalt and availability of calcium oxide in the catalyst structure. Therefore, the amount of produced hydrogen is increased and subsequently hydrogen to carbon monoxide molar ratio is enhanced. In addition, the higher surface area of promoted sample (indicated in Table 1) shows the better tendency of catalyst/sorbent on both activity and selectivity of produced components. The activity of catalysts were in the order of Ca-9Co-4.5Y > Ca-9Co-9Y > Ca-9Co-18Y. The higher amount of yttrium improved the performance of catalyst because increasing the porosity and specific surface area of catalyst could significantly enhance the oxygen carrier capability to transition of lattice oxygen [46,47]. Moreover, increasing the surface area could increase the availability of bifunctional catalyst/sorbent active sites for reaction with methane (Equation (7)). According to this figure, further increase in yttrium content of catalyst/sorbent reveals negative effect on methane conversion, hydrogen yield and average $\mathrm{H}_{2} / \mathrm{CO}$ molar ratio for most temperatures. It could be due to the reduction in the amounts of calcium and cobalt oxides in the structure of catalyst/sorbents and covering the active cites with excessive yttrium oxide $[43,48]$. The comparison of Figures 6 and 7 evidences that yttrium could modify the catalyst performance and increases the methane conversion and hydrogen yield mainly at lower temperatures. For example, methane conversion is increased from about zero at $500{ }^{\circ} \mathrm{C}$ and $95.9 \%$ at $750{ }^{\circ} \mathrm{C}$ for $\mathrm{Ca}-9 \mathrm{Co}$ 
catalyst/sorbent to about $37.2 \%$ at $500{ }^{\circ} \mathrm{C}$ and $97.8 \%$ at $750{ }^{\circ} \mathrm{C}$ for Ca-9Co-4.5Y. When temperature is increased from 500 to $750{ }^{\circ} \mathrm{C}$ the hydrogen yield is changed from about $29.9 \%$ to $83.8 \%$ for Ca-9Co-4.5Y, while it is $0.0 \%$ and $82.2 \%$ for Ca-9Co, respectively. Consequently, Ca-9Co- $4.5 \mathrm{Y}$ is selected as an excellent bifunctional catalyst/sorbent with highest activity in CLSMR process.
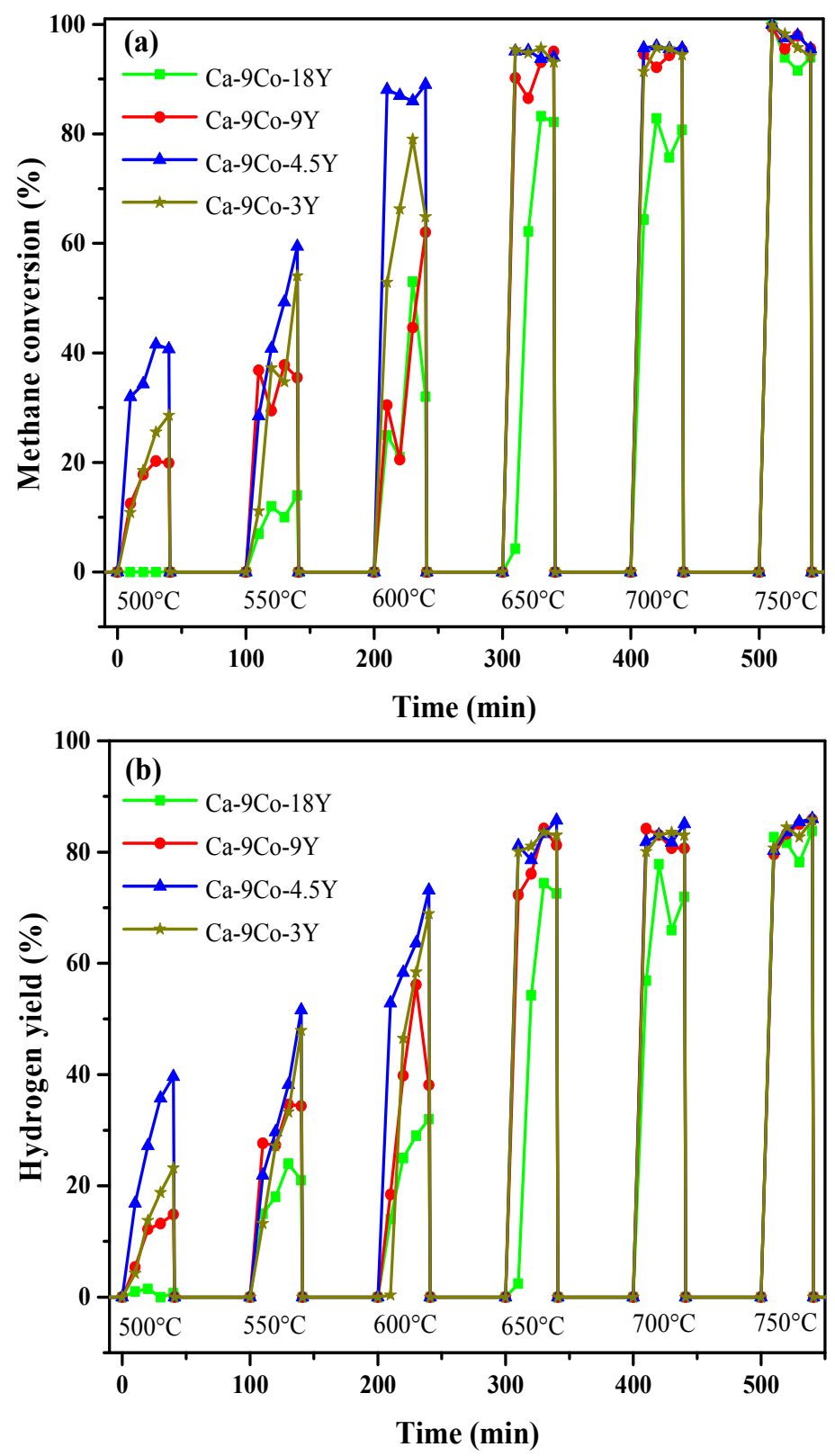

Figure 7. Cont. 


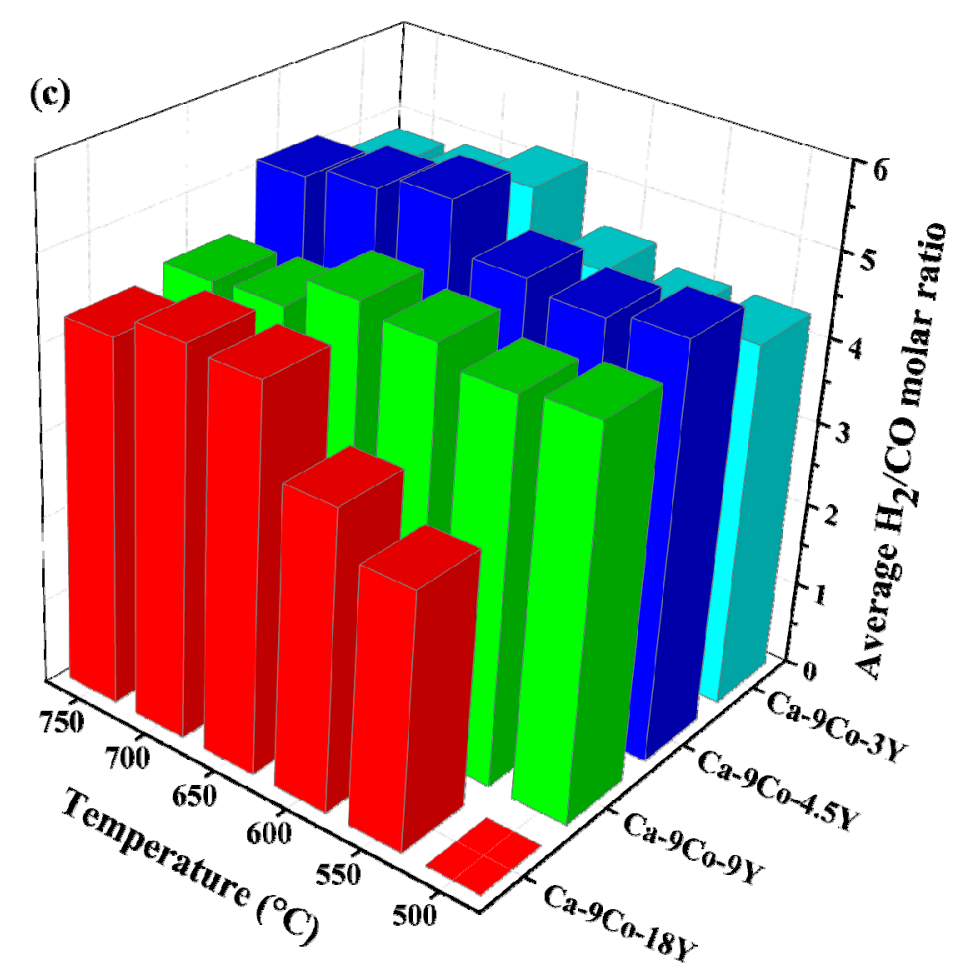

Figure 7. Effect of reaction temperature and yttrium loading on: (a) methane conversion; (b) hydrogen yield; and (c) $\mathrm{H}_{2} / \mathrm{CO}$ molar ratio, at $\mathrm{S} / \mathrm{C}=2$.

The experimental results of a complete isothermal reduction-calcination/oxidation cycle for the samples containing different amount of yttrium $(n=3-18)$ with steam to carbon $(S / C)$ molar ratio of 2 are illustrated in Figure 8. This figure reveals that the bifunctional catalyst/sorbent is an effective agent on the composition of gaseous products. As indicated in Figure 8a, the conversion of methane and production of hydrogen in the reduction step, and release of carbon dioxide in the calcination step are low thus the performance of Ca-9Co-18Y sample seems to be inadequate. The activity of bifunctional catalyst/sorbent is improved by increasing the amount of yttrium in the samples, as shown in Figure 8b-d. It occurs due to the increasing of the sample porosity that results in higher contact between reactant and active sites, as illustrated in the previous section, and controlling of direct activity of the samples toward reacting with methane. According to XRD results (Figure 2), the absence of coke in the used samples shows that released $\mathrm{CO}_{2}$ in the calcination/oxidation step is related to the calcination of $\mathrm{CaCO}_{3}$. Therefore, $\mathrm{H}_{2} / \mathrm{CO}$ molar ratio and the volume percentage of $\mathrm{CO}_{2}$ in the calcination/oxidation section are two important criteria for investigating the samples' behavior. All three samples (Ca-9Co-9Y, Ca-9Co-4.5Y and Ca-9Co-3Y) demonstrate similar profile in the reduction and calcination/oxidation steps; although the one with calcium to yttrium mass ratio of 4.5 shows the best performance according to upon discussions. For example, $\mathrm{H}_{2} / \mathrm{CO}$ molar ratio and volume percentage of $\mathrm{CO}_{2}$ in the calcination/oxidation step are about 4.8 and 6.7 , respectively, for Ca-9Co-9Y sample. These values increase to about 5.3 and 6.9 for Ca-9Co-4.5Y and relatively decrease to about 5.1 and 6.8 for $\mathrm{Ca}-9 \mathrm{Co}-3 \mathrm{Y}$, indicating the better performance $\mathrm{Ca}-9 \mathrm{Co}-4.5 \mathrm{Y}$ catalyst/sorbent. 

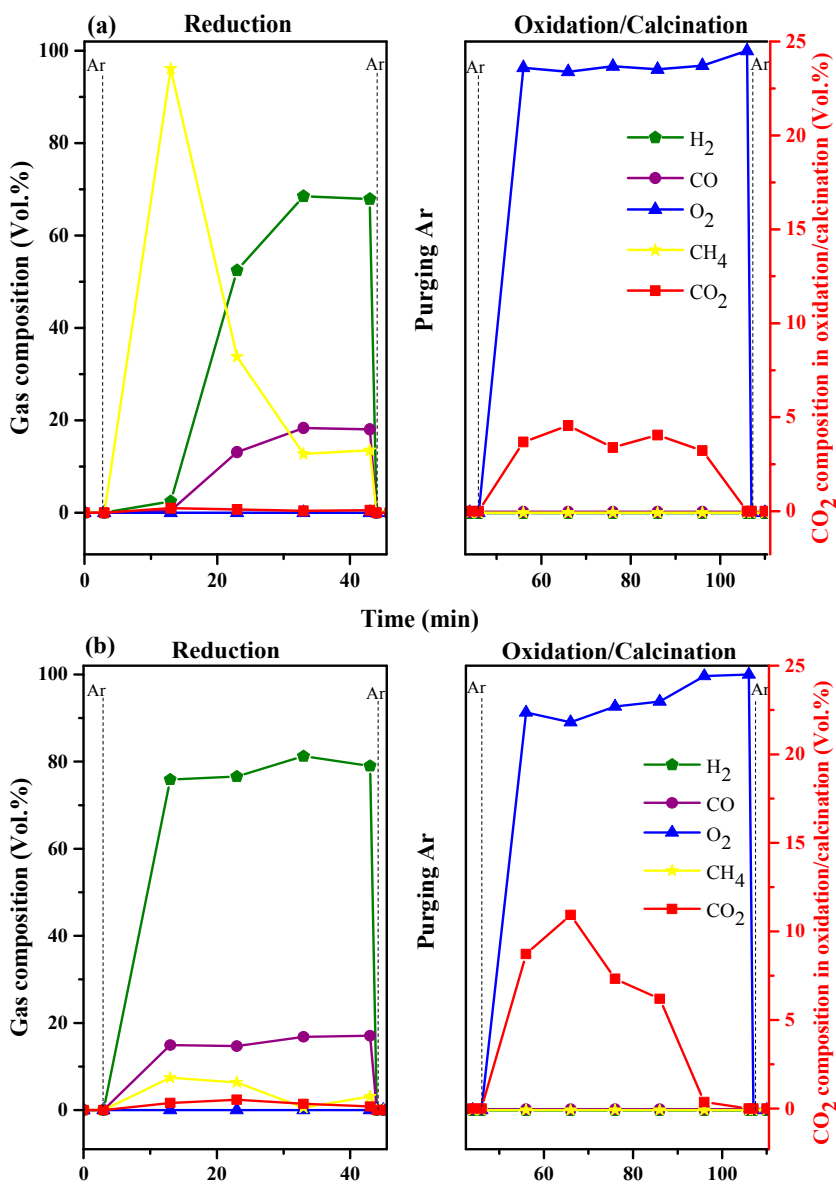

Oxidation/Calcination
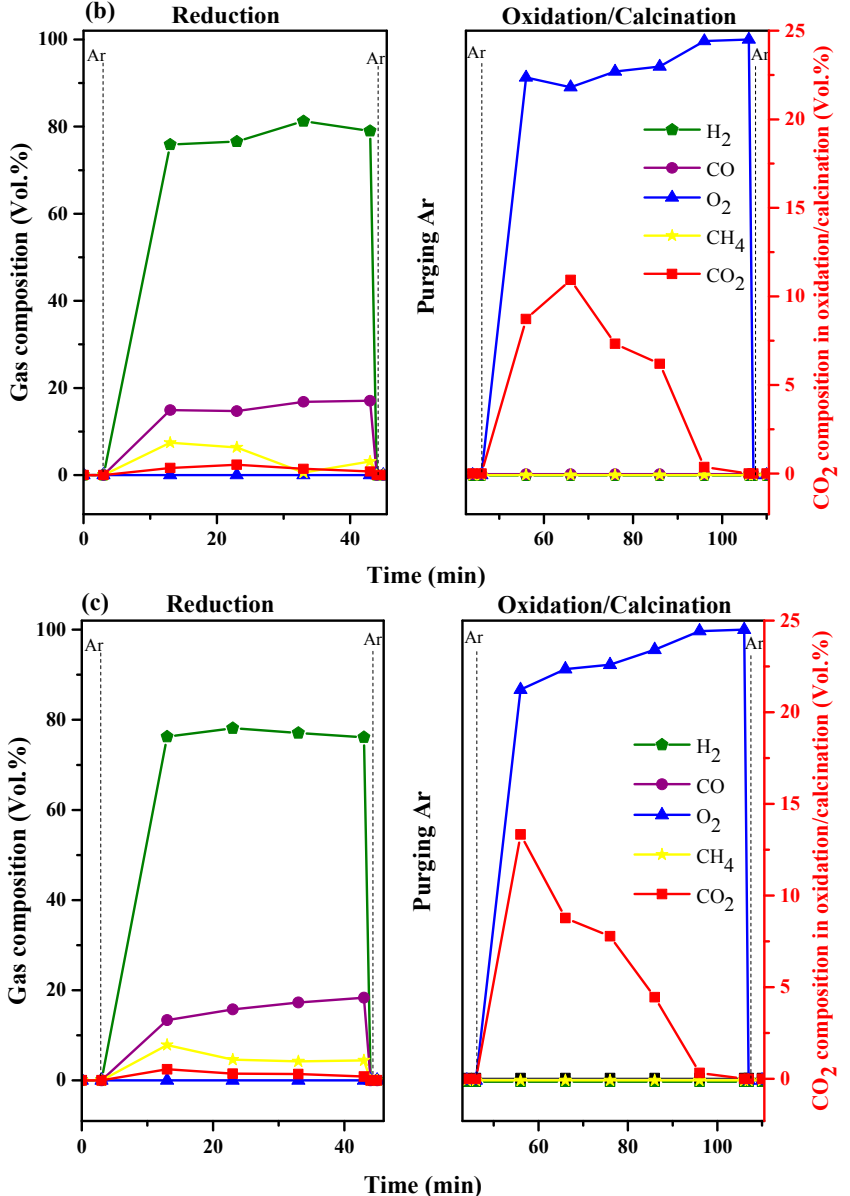

Figure 8. Cont. 


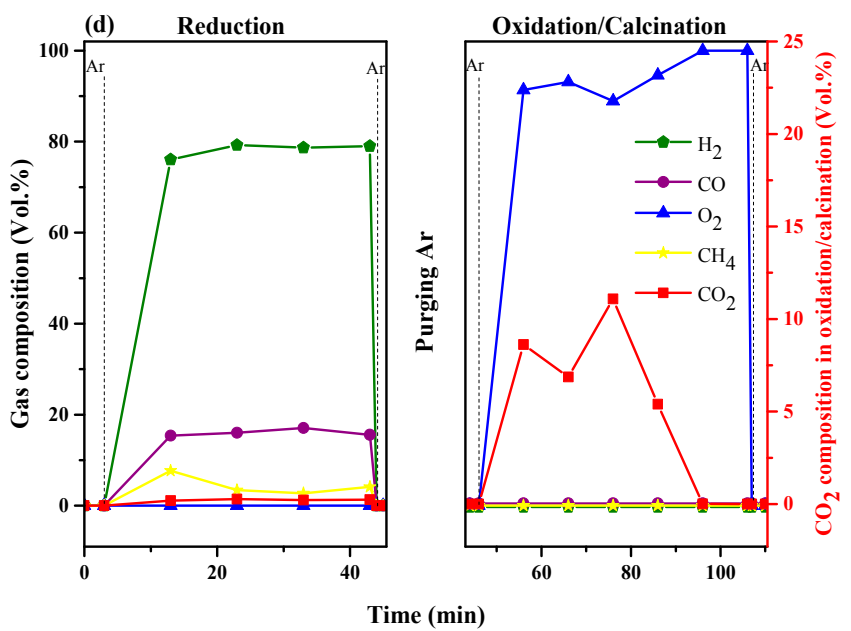

Figure 8. Variation of the gas composition with time for a typical cycle over: (a) Ca-9Co-18Y; (b) Ca-9Co-9Y; (c) Ca-9Co-4.5Y; and (d) Ca-9Co-3Y bifunctional catalyst/sorbents at $650{ }^{\circ} \mathrm{C}, \mathrm{S} / \mathrm{C}=2$.

\section{4. $\mathrm{CO}_{2}$ Concentration in the Reaction Media}

The evolution of gas compositions of four bifunctional catalyst/sorbents containing yttrium ( $\mathrm{n}=3.0,4.5,9.0$, and 18.0) illustrated that the average volume percentage of $\mathrm{CO}_{2}$ in the reaction media was about $0.5 \mathrm{vol} \%$ at lower temperatures $\left(500-550^{\circ} \mathrm{C}\right)$ and 2.1 at higher temperatures $\left(750{ }^{\circ} \mathrm{C}\right)$. Antzara et al. [6] reported the performance of different oxygen carriers including $\mathrm{NiO} / \mathrm{ZrO}_{2}, \mathrm{NiO} / \mathrm{TiO}_{2}$, $\mathrm{NiO} / \mathrm{SiO}_{2}$ and $\mathrm{NiO} / \mathrm{Al}_{2} \mathrm{O}_{3}$ in CLR process at $650{ }^{\circ} \mathrm{C}$. The results exhibited high activity with the high composition of hydrogen about $75-80 \%$, while the composition of carbon dioxide in the dry gaseous product was in the order of $10-12 \%$. In the other study, Ryden et al. [49] tested $\mathrm{NiO} / \mathrm{MgAl}_{2} \mathrm{O}_{4}$ oxygen carrier in the chemical looping reforming of methane process. The experiment was performed at high temperature $\left(888-914{ }^{\circ} \mathrm{C}\right)$ in the fuel reactor and the result represented that the average composition of $\mathrm{CO}_{2}$ was about $11.5 \%$. To assist the reader, a summary table is presented (Table 2). The comparison between the obtained result and literature data clearly revealed a reduction of about $10 \%$ in the composition of $\mathrm{CO}_{2}$ in produced dry gas. Therefore, the modified CLSMR process developed in this work acts as an effective method for increasing the purity of syngas in the output stream.

Table 2. Comparison of $\mathrm{CO}_{2}$ volume percentage in the product stream.

\begin{tabular}{ccccc}
\hline Sample & $\begin{array}{c}\text { Reaction } \\
\text { Temperature }\left({ }^{\circ} \mathbf{C}\right)\end{array}$ & Process Type & $\begin{array}{c}\text { Average Composition of } \mathrm{CO}_{2} \\
(\text { vol \%) in Reduction Step }\end{array}$ & References \\
\hline $\mathbf{N i O} / \mathbf{Z r O}_{2}$ & 650 & CLSMR & 12 & {$[6]$} \\
$\mathbf{N i O} / \mathbf{M g A l}_{2} \mathbf{O}_{4}$ & $888-914$ & CLSMR & 11.5 & {$[49]$} \\
$\mathbf{C a}-9 C_{0}-4.5 Y$ & 650,750 & Modified CLSMR & $1.3,2.1$ & This Study \\
\hline
\end{tabular}

\subsection{Life Time of Ca-9Co and Ca-9Co-4.5Y Bifunctional Catalyst/Sorbents}

With the aim of investigating the stability of bifunctional catalyst/sorbents, the performance of optimized sample containing Ca-9Co and Ca-9Co-4.5Y were tested through 16 consecutive cycles. Therefore, the variation of methane conversion with time was determined at $700{ }^{\circ} \mathrm{C}$, as shown in Figure 9. The methane conversion of Ca-9Co is relatively low in the first and second cycles. It might be due to the incomplete oxidation of solid phase in the reduction step. The methane conversion increases to about $99.5 \%$ from cycle 3 to 10 and then decreases by about $2.5 \%$ at the last cycle. It shows that the activity of Ca-9Co catalyst/sorbent is reduced after a few cycles. Sintering, agglomeration and pore blockage are the main reasons for this event. However, the methane conversion of Ca-9Co-4.5Y catalyst is about $99.5 \%$ and remains rather constant over 16 redox cycles. In fact, yttrium improved the thermal stability of the sample and improved the catalyst stability and resistance against catalyst destruction. 
In addition, the carbon balance on the data of optimal sample in the lifetime test at $700{ }^{\circ} \mathrm{C}$ was performed during a complete cycle including reduction and calcination/oxidation steps. The results revealed the carbon balance of about $84-88 \%$, which might be due to the thermal cracking of methane on the wall of tubular reactor.

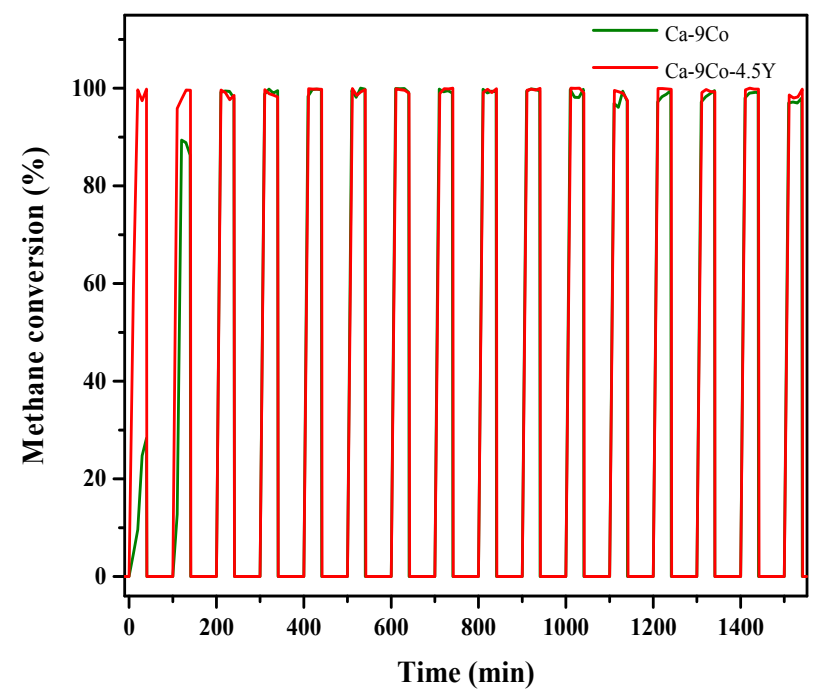

Figure 9. Life time of Ca-9Co and Ca-9Co-4.5Y samples during 16 redox cycles at $700{ }^{\circ} \mathrm{C}$.

\subsection{Characterization of Used and Regenerated Catalyst/Sorbents}

The FESEM images of used (after carbonation) and regenerated (after calcination/oxidation) Ca-9Co and Ca-9Co-4.5Y catalyst/sorbents are displayed in Figure 10. A comparison of fresh samples (Figure 3b,c) and used ones (Figure 10a,c) demonstrates the large agglomeration in the formation of $\mathrm{CaCO}_{3}$ [5], sintering, pore blockage and changing the morphology of bifunctional catalyst/sorbents during the direct reaction with methane in the reduction step. Figure 10b,d represents that the regenerated catalysts in calcination/oxidation step can greatly return to the initial structural morphology. Therefore, it proves the stable performance of mentioned catalyst/sorbent during successive cycles in the CLSMR process.

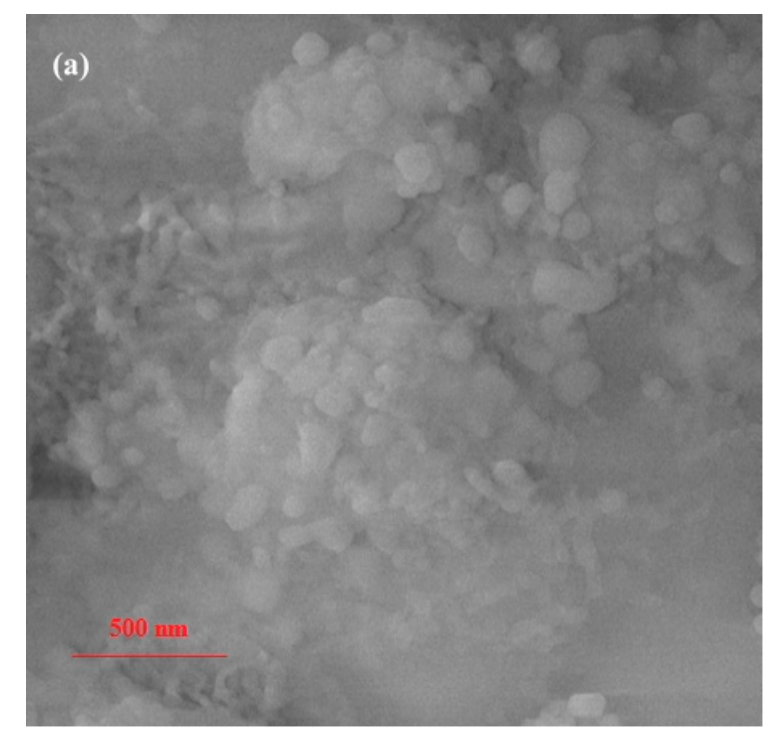

Figure 10. Cont. 

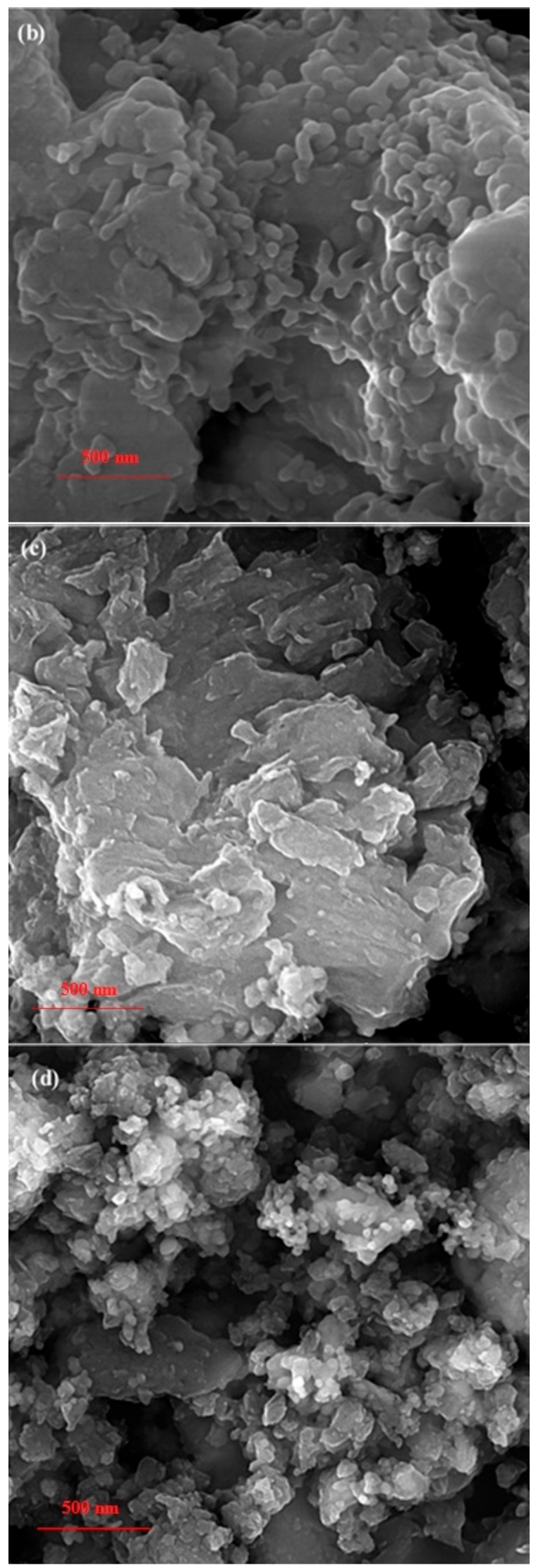

Figure 10. FESEM images of: (a) used Ca-9Co after reduction step; (b) regenerated Ca-9Co after calcination/oxidation step; (c) used Ca-9Co-4.5Y after reduction step; and (d) regenerated Ca-9Co-4.5Y after calcination/oxidation step. 
The nitrogen adsorption-desorption isotherm and pore size distribution of optimum sample after reduction step is depicted in Figure 11. It showed the type II isotherm with the hysteresis loops of type $\mathrm{H} 3$.

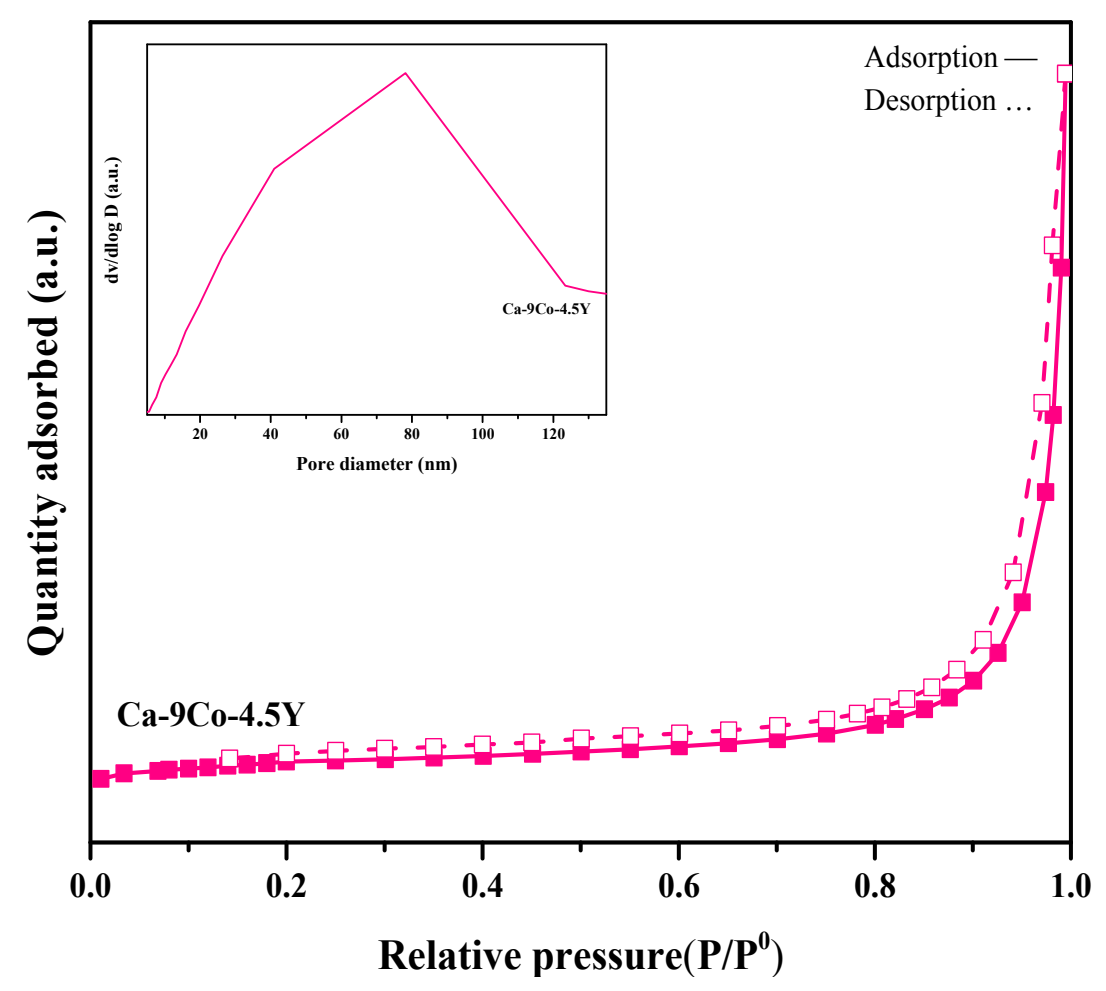

Figure 11. $\mathrm{N}_{2}$ adsorption-desorption isotherm and pore size distribution of used optimal sample (Ca-9Co-4.5Y).

BET analysis related to this sample is performed and the results are explained as $6.5 \mathrm{~m}^{2} / \mathrm{g}$ BET surface area and 0.055 pore volume while pore diameter is equal to $29.56 \mathrm{~nm}$. A comparison between this result and the ones of fresh sample (Table 1) indicates that the surface area of used Ca-9Co-4.5Y is reduced from $17.9 \mathrm{~m}^{2} / \mathrm{g}$ to $6.5 \mathrm{~m}^{2} / \mathrm{g}$, which could be due to the pore blockage by sorption of $\mathrm{CO}_{2}$ during the reduction test. The formation of $\mathrm{CaCO}_{3}$ through the reaction of $\mathrm{CO}_{2}$ and $\mathrm{CaO}$ and the destruction of the structure especially in the elementary cycles make the structure more compressed. The loss of catalyst porosity during the reduction can be observed from reported pore volume (reduction from $0.161 \mathrm{~cm}^{3} / \mathrm{g}$ to $0.055 \mathrm{~cm}^{3} / \mathrm{g}$ ), which confirms the FESEM result (Figure 10b).

In accordance with XRD results of used samples after about $26 \mathrm{~h}$ exposure (16 redox cycles) (Figure 2), the absence of coke revealed that all of carbon in the structure of used samples were presented in the formation of $\mathrm{CaCO}_{3}$. Therefore, the relative amount of carbon estimated by EDX analysis of used samples is a good factor for evaluating the amount of calcium has participated in the reaction media. Figure 12a,b demonstrates the EDX results of Ca-9Co and Ca-9Co-4.5Y bifunctional catalyst/sorbents after reduction step, respectively. According to EDX results, the amount of carbon for the used Ca-9Co is about 5.3\% and increases to about $8.0 \%$ for Ca-9Co-4.5Y. Hence, it was evidenced that the higher progress of main reaction in the presence of $\mathrm{Ca}-9 \mathrm{Co}-4.5 \mathrm{Y}$ bifunctional catalyst/sorbent and increasing the production of hydrogen. The results are in a good agreement with pervious results (Figures $6 \mathrm{~b}$ and $7 \mathrm{~b}$ ). 

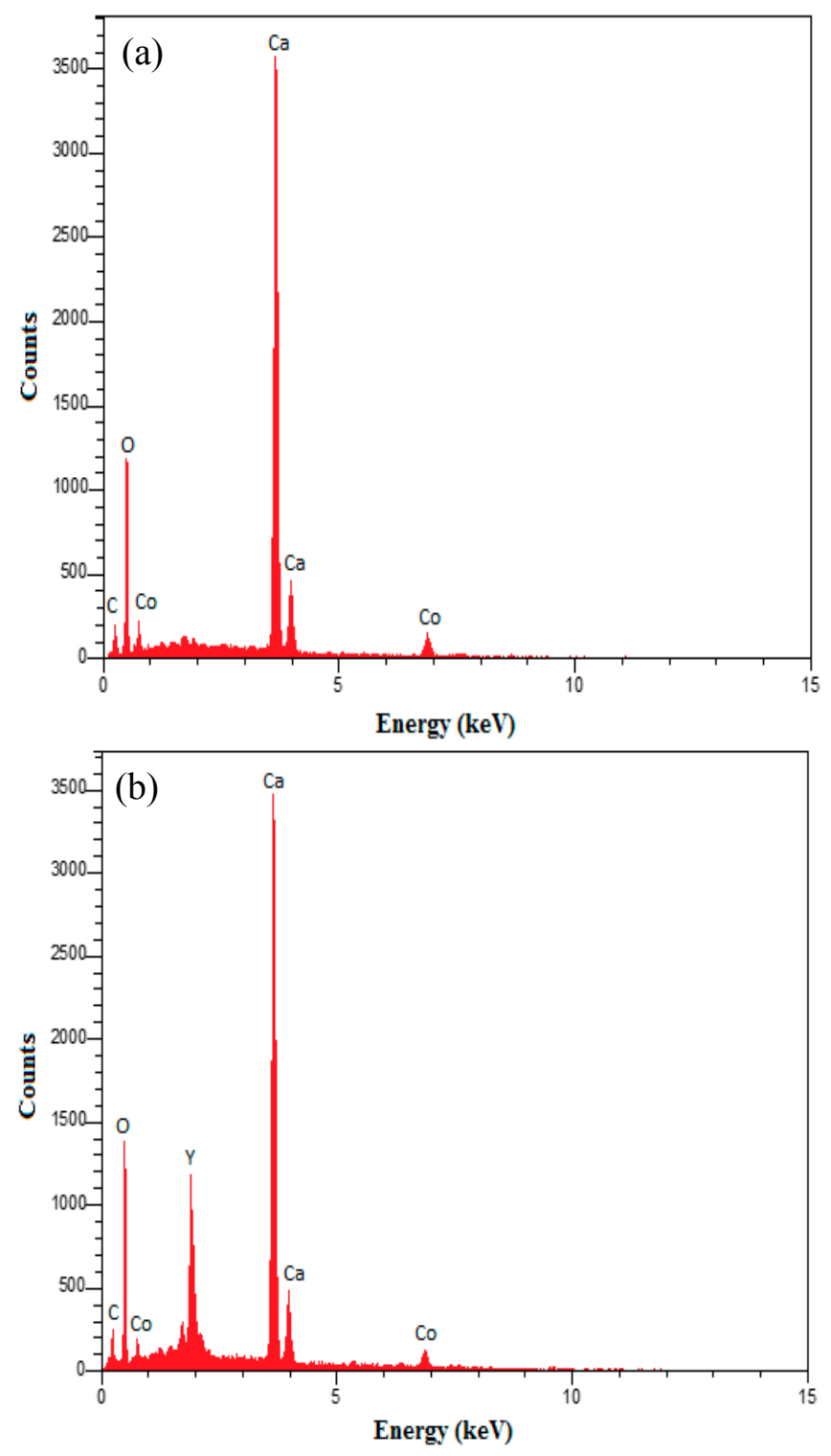

Figure 12. EDX analysis of used: (a) Ca-9Co; and (b) Ca-9Co-4.5Y.

\section{Experimental Methods}

\subsection{Preparation of Bifunctional Catalyst/Sorbent}

The bifunctional catalyst/sorbents containing Ca-mCo and Ca-mCo-nY ( $\mathrm{m}$ and $\mathrm{n}$ demonstrate the calcium to cobalt and calcium to yttrium mass ratios, respectively) were synthesized with co-precipitation method. Firstly, Ca-Co bifunctional catalyst/sorbents were prepared by adding a certain amount of $\mathrm{Co}\left(\mathrm{NO}_{3}\right)_{2} \cdot 6 \mathrm{H}_{2} \mathrm{O}$ (Merck, Darmstadt, Germany) solution to $\mathrm{Ca}\left(\mathrm{NO}_{3}\right)_{2} \cdot 4 \mathrm{H}_{2} \mathrm{O}$ (Merck) solution with different calcium to cobalt ratios. Then, the precursor aqueous solutions were mixed together over a wide range of $1.5-\infty(\mathrm{Ca} / \mathrm{Co})$ in a three necked balloon and $0.5 \mathrm{M} \mathrm{NaOH}$ as the precipitant agent was added drop-by-drop with vigorous stirring. The addition of precipitant was continued isothermally at $80^{\circ} \mathrm{C}$ until the $\mathrm{pH}$ of 11 . Then, it was aged for about $15 \mathrm{~h}$. After that, the precipitate was filtered and washed repeatedly with warm DI water. The samples were dried at $100^{\circ} \mathrm{C}$ overnight and calcined at $700{ }^{\circ} \mathrm{C}$ for $3 \mathrm{~h}$ with the heating ramp of $4{ }^{\circ} \mathrm{C} / \mathrm{min}$. In addition, it should be noted that the samples undergo a calcination/oxidation step at $750{ }^{\circ} \mathrm{C}$ for $1 \mathrm{~h}$ prior to each experiments. The pure calcium oxide is labeled as synthesized $\mathrm{CaO}$. 
The synthesis of yttrium promoted calcium-cobalt bifunctional catalyst/sorbent (Ca-mCo-nY, where $\mathrm{n}$ shows the mass ratio of $\mathrm{Ca} / \mathrm{Y}=3,4.5,9$ and 18) was performed with the same procedure. For this purpose, a $0.25 \mathrm{M}$ aqueous solution of $\mathrm{Y}\left(\mathrm{NO}_{3}\right)_{3} \cdot 6 \mathrm{H}_{2} \mathrm{O}$ was added to initial solution of calcium-cobalt and precipitation was performed as discussed previously.

\subsection{Samples Characterization}

Various characterization techniques were applied for analyzing the textural structure, specific surface area and the influence of reactive features on the samples. The identification of crystalline phases in solid samples was achieved using XRD. The XRD patterns were attained by name of a Bruker $\mathrm{D} 8$ advanced powder diffractometer by monochromatic $\mathrm{CuK} \alpha$ radiation, operated at $40 \mathrm{kV}$ and $40 \mathrm{~mA}$. Scanning was performed in a step-scan mode, with a step size of $0.1^{\circ}$ for $2 \theta$ between $10-90$ and a scan time of $2 \mathrm{~s}$ at each step. Specific surface area and cumulative pore volume of the samples were determined using the BET and BJH methods from $\mathrm{N}_{2}$ adsorption-desorption isotherms, respectively. A Micrometric ASAP 2020 instrument was applied for BET tests. Before the analysis, the samples were degassed at $250^{\circ} \mathrm{C}$ for a least $3 \mathrm{~h}$. For investigating the surface morphology and elemental composition of the fresh and used catalysts, FESEM and EDX were carried out by a MIRA3 TESCAN apparatus. The TEM measurements were carried out using Zeiss-EM10C TEM unite (100 KV).

\subsection{Catalytic Evaluation}

The performance of prepared catalyst/sorbents was investigated in a fixed bed reactor $(65 \mathrm{~cm}$ length and $1.2 \mathrm{~cm}$ inner diameter) in CLSMR process, which was electrically heated in a vertical furnace. The temperature of catalyst/sorbents was monitored during the process with a K-type thermocouple. This thermocouple was located in the center of catalyst bed and fixed the favorable temperature during each cycle. For each activity test, an amount of $1.5 \mathrm{~g}$ powdered catalyst/sorbent was exposed to a gaseous streams containing $60 \mathrm{~mL} / \mathrm{min}$ reducing gas $\left(\mathrm{CH}_{4}\right)$ diluted in argon $(120 \mathrm{~mL} / \mathrm{min})$ in reduction step, and $20 \mathrm{vol} \%$ oxidizing gas $\left(\mathrm{O}_{2}\right)$ balanced with argon in the calcination/oxidation section. The flow rates of these gases was intently controlled using three distinct mass flow controllers (Unit instruments, model UFC 1661). The desired amount of water was injected with a high accurate syringe pump to a heated line before the reactor and then the generated steam was mixed with inlet gas stream and fed to the reactor in the reduction step. The reduction section was performed isothermally at $500-750{ }^{\circ} \mathrm{C}$ for $45 \mathrm{~min}$ and the calcination/oxidation period was carried out at $700{ }^{\circ} \mathrm{C}$ for about $1 \mathrm{~h}$. Actually, the calcination was conducted until carbon dioxide concentration became zero in the produced gas. The calcination and oxidation steps are merged; thus, in the regeneration step (containing calcination and oxidation), a mixture of oxygen and carrier is injected simultaneously with increasing the bed temperature. Thus, the unreacted oxygen is present in the reactor effluent in regeneration step (Figure 13). Each section in a cycle was separated via 3 min pure argon purging with the purpose of driving the remained gases out of the bed. A condenser followed by a separator was considered for separating excessive water from gaseous products. An online gas chromatograph (Bruker 450) was applied to analyze composition of obtained dry gas for each $9 \mathrm{~min}$. The schematic of experimental setup is shown in Figure 13.

According to following equations, methane conversion $\left(\mathrm{X}_{\mathrm{CH}_{4}}\right)$ and hydrogen production yield $\left(Y_{\mathrm{H}_{2}}\right)$ were calculated for evaluating the activity of catalyst/sorbents in the CLSMR process.

$$
\begin{gathered}
\mathrm{X}_{\mathrm{CH}_{4}}=\frac{\left(\mathrm{F}_{\mathrm{CH}_{4} \text { in }}\right)-\left(\mathrm{F}_{\mathrm{CH}_{4} \text { out }}\right)}{\left(\mathrm{F}_{\mathrm{CH}_{4} \text { in }}\right)} \times 100 \\
Y_{\mathrm{H}_{2}}=\frac{\mathrm{F}_{\mathrm{H}_{2}}}{2 \times\left(\mathrm{F}_{\mathrm{CH}_{4} \text { in }}\right)} \times 100
\end{gathered}
$$


where $\mathrm{F}_{\mathrm{CH}_{4} \text { in }}, \mathrm{F}_{\mathrm{CH}_{4} \text { out }}$ and $\mathrm{F}_{\mathrm{H}_{2}}$ represents the inlet and outlet molar flow rates of methane $(\mathrm{mol} / \mathrm{min})$ and the outlet molar flow rate of hydrogen $(\mathrm{mol} / \mathrm{min})$, respectively.

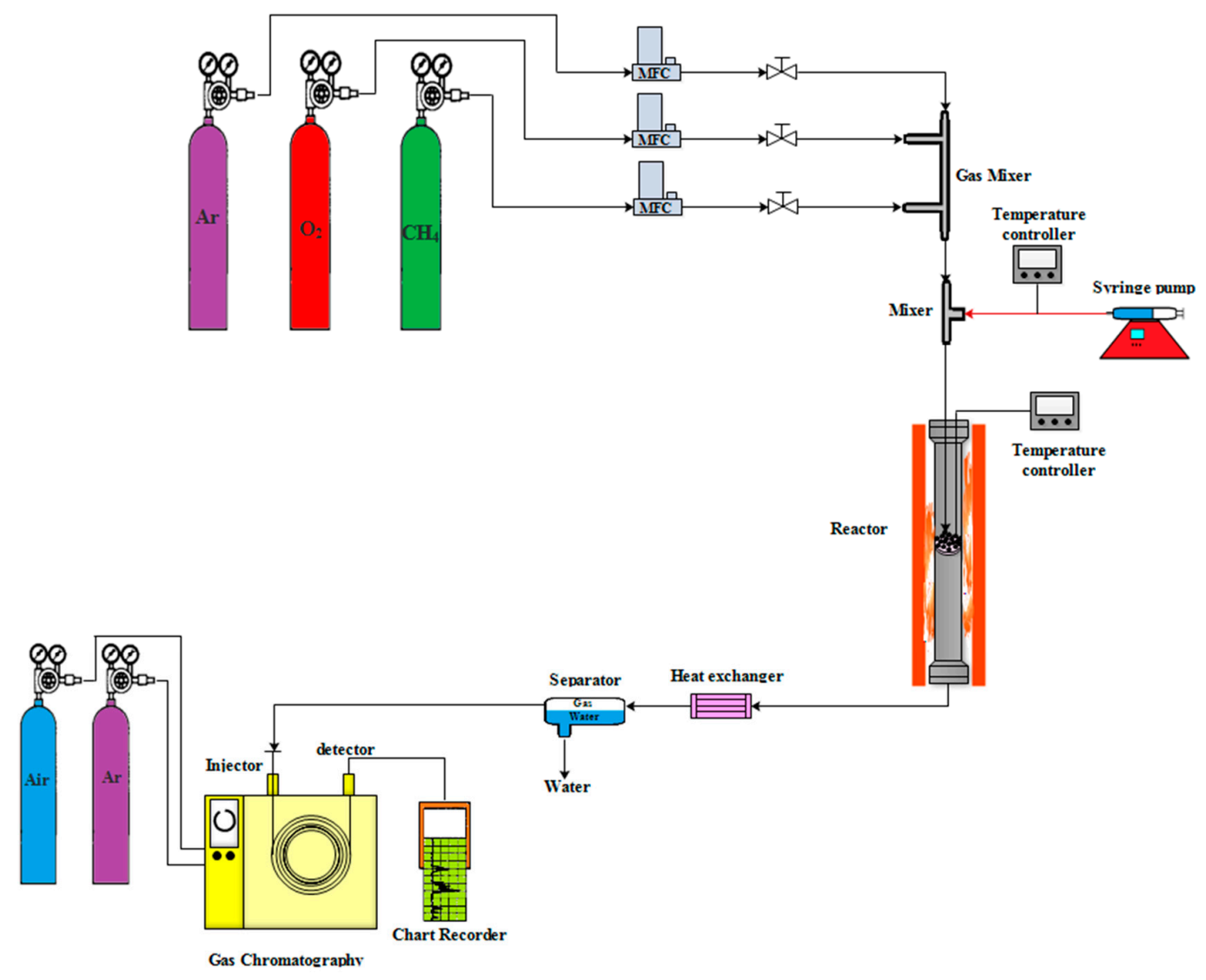

Figure 13. Experimental set up applied for CLSMR process.

\section{Conclusions}

Production of hydrogen rich syngas was investigated experimentally in a new CLSMR process via a direct reaction with bifunctional catalyst/sorbent and methane in the presence of steam. Co-precipitation method was applied to prepare Ca-nCo (n: $\mathrm{Ca} / \mathrm{Co}$ ratio $=1.5-\infty$ (pure $\mathrm{CaO})$ ), and Ca-nCo-mY (m: Ca/Y ratio $=3-18)$ bifunctional catalyst/sorbents. With the purpose of obtaining optimal $\mathrm{Ca} / \mathrm{Co}$ and $\mathrm{Ca} / \mathrm{Y}$ mass ratios and illustrating the effect of reaction temperature, the synthesized samples were tested in CLSMR process at different reaction temperatures $\left(500-750{ }^{\circ} \mathrm{C}\right)$. The Ca-9Co-4.5Y showed the highest catalytic performance and lowest activity reduction compared to all other samples. For yttrium promoted Ca-9Co $(\mathrm{m}=4.5)$, the methane conversion, hydrogen yield and $\mathrm{H}_{2} / \mathrm{CO}$ molar ratio, respectively, reached about $95.8 \%, 82.9 \%$ and 5.3 at $700{ }^{\circ} \mathrm{C}$, while these parameters were about $95 \%, 81.5 \%$ and 5.2 for Ca-9Co. The XRD results of fresh samples revealed that the formation of calcium-cobalt spinel was prevented in the presence of yttrium. The FESEM images of fresh samples illustrated that the agglomerated structure with low porosity appeared with the addition of cobalt, while yttrium showed the potential for the modification and improvement of this structure and increased the catalyst/sorbent surface area. The characterization of used samples after reduction step demonstrated that the methane decomposition reaction and therefore the production of elemental carbon could not occur in this process. Moreover, the progress in the direct reaction of bifunctional catalyst/sorbent with methane along with steam reforming of methane on the surface of catalyst was confirmed by EDX analysis of reduced samples after reduction test. Comparing the XRD and FESEM of fresh, used and regenerated samples confirmed the nearly complete regeneration of yttrium promoted bifunctional catalyst/sorbent. 
Author Contributions: S.A.-E. and A.H. conceived and designed the experiments; S.A.-E. performed the experiments; S.A.-E. performed catalyst synthesis; S.A.-E. and A.H. analyzed the data; M.R. and P.K. contributed reagents/materials/analysis tools; M.R. and P.K. participated in the analysis and interpretation of characterization results; and S.A.-E. wrote the paper.

Conflicts of Interest: The authors declare no conflict of interest.

\section{References}

1. Abánades, A.; Ruiz, E.; Ferruelo, E.; Hernández, F.; Cabanillas, A.; Martínez-Val, J.; Rubio, J.A.; López, C.; Gavela, R.; Barrera, G.; et al. Experimental analysis of direct thermal methane cracking. Int. J. Hydrogen Energy 2011, 36, 12877-12886. [CrossRef]

2. Jabbour, K.; Massiani, P.; Davidson, A.; Casale, S.; El Hassan, N. Ordered mesoporous “one-pot” synthesized $\mathrm{Ni}-\mathrm{Mg}(\mathrm{Ca})-\mathrm{Al}_{2} \mathrm{O}_{3}$ as effective and remarkably stable catalysts for combined steam and dry reforming of methane (csdrm). Appl. Catal. B 2016. [CrossRef]

3. Abbasi, M.; Farniaei, M.; Rahimpour, M.R.; Shariati, A. Enhancement of hydrogen production and carbon dioxide capturing in a novel methane steam reformer coupled with chemical looping combustion and assisted by hydrogen perm-selective membranes. Energy Fuels 2013, 27, 5359-5372. [CrossRef]

4. Wang, Y.; Chen, M.; Liang, T.; Yang, Z.; Yang, J.; Liu, S. Hydrogen generation from catalytic steam reforming of acetic acid by Ni/attapulgite catalysts. Catalysts 2016, 6, 172. [CrossRef]

5. Antzara, A.; Heracleous, E.; Lemonidou, A.A. Energy efficient sorption enhanced-chemical looping methane reforming process for high-purity $\mathrm{H}_{2}$ production: Experimental proof-of-concept. Appl. Energy 2016, 180, 457-471. [CrossRef]

6. Antzara, A.; Heracleous, E.; Silvester, L.; Bukur, D.B.; Lemonidou, A.A. Activity study of NiO-based oxygen carriers in chemical looping steam methane reforming. Catal. Today 2016, 272, 32-41. [CrossRef]

7. Khan, M.N.; Shamim, T. Investigation of hydrogen generation in a three reactor chemical looping reforming process. Appl. Energy 2016, 162, 1186-1194. [CrossRef]

8. Ni, M.; Leung, M.K.; Sumathy, K.; Leung, D.Y. Potential of renewable hydrogen production for energy supply in Hong Kong. Int. J. Hydrogen Energy 2006, 31, 1401-1412. [CrossRef]

9. Forutan, H.R.; Karimi, E.; Hafizi, A.; Rahimpour, M.R.; Keshavarz, P. Expert representation chemical looping reforming: A comparative study of $\mathrm{Fe}, \mathrm{Mn}, \mathrm{Co}$ and $\mathrm{Cu}$ as oxygen carriers supported on $\mathrm{Al}_{2} \mathrm{O}_{3}$. J. Ind. Eng. Chem. 2015, 21, 900-911. [CrossRef]

10. Zhou, C.; Shah, K.; Doroodchi, E.; Moghtaderi, B. Equilibrium thermodynamic analyses of methanol production via a novel chemical looping carbon arrestor process. Energy Convers. Manag. 2015, 96, 392-402. [CrossRef]

11. Yahom, A.; Powell, J.; Pavarajarn, V.; Onbhuddha, P.; Charojrochkul, S.; Assabumrungrat, S. Simulation and thermodynamic analysis of chemical looping reforming and $\mathrm{CO}_{2}$ enhanced chemical looping reforming. Chem. Eng. Res. Des. 2014, 92, 2575-2583. [CrossRef]

12. Hafizi, A.; Jafari, M.; Rahimpour, M.R.; Hassanajili, S. Experimental investigation of sorption enhanced chemical looping reforming for high purity hydrogen production using $\mathrm{CeO}_{2}-\mathrm{CaO} \mathrm{CO}_{2}$ sorbent and $15 \mathrm{Fe}-5 \mathrm{Ca} / \mathrm{Al}_{2} \mathrm{O}_{3}$ oxygen carrier. J. Taiwan Inst. Chem. Eng. 2016. [CrossRef]

13. Ghasemzadeh, K.; Liguori, S.; Morrone, P.; Iulianelli, A.; Piemonte, V.; Babaluo, A.A.; Basile, A. $\mathrm{H}_{2}$ production by low pressure methanol steam reforming in a dense Pd-Ag membrane reactor in CO-current flow configuration: Experimental and modeling analysis. Int. J. Hydrogen Energy 2013, 38, 16685-16697. [CrossRef]

14. Sengupta, S.; Deo, G. Modifying alumina with $\mathrm{CaO}$ or $\mathrm{MgO}$ in supported $\mathrm{Ni}$ and Ni-CO catalysts and its effect on dry reforming of $\mathrm{CH}_{4}$. J. $\mathrm{CO}_{2}$ Util. 2015, 10, 67-77. [CrossRef]

15. Agrawal, V.; Srivastava, V.C. Simulation of fluidized bed reactor for producing synthesis gas by catalytic $\mathrm{CH}_{4}-\mathrm{CO}_{2}$ reforming. J. $\mathrm{CO}_{2}$ Util. 2014, 5, 10-16. [CrossRef]

16. Hafizi, A.; Rahimpour, M.R.; Hassanajili, S. Hydrogen production by chemical looping steam reforming of methane over Mg promoted iron oxygen carrier: Optimization using design of experiments. J. Taiwan Inst. Chem. Eng. 2016. [CrossRef] 
17. LeValley, T.L.; Richard, A.R.; Fan, M. Development of catalysts for hydrogen production through the integration of steam reforming of methane and high temperature water gas shift. Energy 2015, 90, 748-758. [CrossRef]

18. Hafizi, A.; Rahimpour, M.R.; Hassanajili, S. High purity hydrogen production via sorption enhanced chemical looping reforming: Application of $22 \mathrm{Fe}_{2} \mathrm{O}_{3} / \mathrm{MgAl}_{2} \mathrm{O}_{4}$ and $22 \mathrm{Fe}_{2} \mathrm{O}_{3} / \mathrm{Al}_{2} \mathrm{O}_{3}$ as oxygen carriers and cerium promoted $\mathrm{CaO}$ as $\mathrm{CO}_{2}$ sorbent. Appl. Energy 2016, 169, 629-641. [CrossRef]

19. Vozniuk, O.; Agnoli, S.; Artiglia, L.; Vassoi, A.; Tanchoux, N.; Di Renzo, F.; Granozzi, G.; Cavani, F. Towards an improved process for hydrogen production: The chemical-loop reforming of ethanol. Green Chem. 2016, 18, 1038-1050. [CrossRef]

20. Dewoolkar, K.D.; Vaidya, P.D. Improved hydrogen production by sorption-enhanced steam methane reforming over hydrotalcite-and calcium-based hybrid materials. Energy Fuels 2015, 29, 3870-3878. [CrossRef]

21. Freitas, A.C.D.; Guirardello, R. Thermodynamic analysis of methane reforming with $\mathrm{CO}_{2}, \mathrm{CO}_{2}+\mathrm{H}_{2} \mathrm{O}$, $\mathrm{CO}_{2}+\mathrm{O}_{2}$ and $\mathrm{CO}_{2}+$ air for hydrogen and synthesis gas production. J. $\mathrm{CO}_{2}$ Util. 2014, 7, 30-38. [CrossRef]

22. Du, Y.-L.; Wu, X.; Cheng, Q.; Huang, Y.-L.; Huang, W. Development of Ni-based catalysts derived from hydrotalcite-like compounds precursors for synthesis gas production via methane or ethanol reforming. Catalysts 2017, 7, 70. [CrossRef]

23. Xu, P.; Zhou, Z.; Zhao, C.; Cheng, Z. Catalytic performance of Ni/CaO-Ca $\mathrm{Al}_{6} \mathrm{O}_{14}$ bifunctional catalyst extrudate in sorption-enhanced steam methane reforming. Catal. Today 2016, 259, 347-353. [CrossRef]

24. Farniaei, M.; Abbasi, M.; Rahnama, H.; Rahimpour, M.R.; Shariati, A. Syngas production in a novel methane dry reformer by utilizing of tri-reforming process for energy supplying: Modeling and simulation. J. Nat. Gas Sci. Eng. 2014, 20, 132-146. [CrossRef]

25. Hafizi, A.; Rahimpour, M.R.; Hassanajili, S. Calcium promoted $\mathrm{Fe} / \mathrm{Al}_{2} \mathrm{O}_{3}$ oxygen carrier for hydrogen production via cyclic chemical looping steam methane reforming process. Int. J. Hydrogen Energy 2015, 40, 16159-16168. [CrossRef]

26. Karimi, E.; Forutan, H.; Saidi, M.; Rahimpour, M.R.; Shariati, A. Experimental study of chemical-looping reforming in a fixed-bed reactor: Performance investigation of different oxygen carriers on $\mathrm{Al}_{2} \mathrm{O}_{3}$ and $\mathrm{TiO}_{2}$ support. Energy Fuels 2014, 28, 2811-2820. [CrossRef]

27. Martini, M.; van den Berg, A.; Gallucci, F.; van Sint Annaland, M. Investigation of the process operability windows for $\mathrm{Ca}-\mathrm{Cu}$ looping for hydrogen production with $\mathrm{CO}_{2}$ capture. Chem. Eng. J. 2016, 303, 73-88. [CrossRef]

28. Dou, B.; Wang, C.; Song, Y.; Chen, H.; Jiang, B.; Yang, M.; Xu, Y. Solid sorbents for in-situ $\mathrm{CO}_{2}$ removal during sorption-enhanced steam reforming process: A review. Renew. Sustain. Energy Rev. 2016, 53, 536-546. [CrossRef]

29. Yancheshmeh, M.S.; Radfarnia, H.R.; Iliuta, M.C. High temperature $\mathrm{CO}_{2}$ sorbents and their application for hydrogen production by sorption enhanced steam reforming process. Chem. Eng. J. 2016, 283, 420-444. [CrossRef]

30. Li, C.-C.; Cheng, J.-Y.; Liu, W.-H.; Huang, C.-M.; Hsu, H.-W.; Lin, H.-P. Enhancement in cyclic stability of the $\mathrm{CO}_{2}$ adsorption capacity of $\mathrm{CaO}$-based sorbents by hydration for the calcium looping cycle. J. Taiwan Inst. Chem. Eng. 2014, 45, 227-232. [CrossRef]

31. Zhong, X.; Xie, W.; Wang, N.; Duan, Y.; Shang, R.; Huang, L. Dolomite-derived ni-based catalysts with Fe modification for hydrogen production via auto-thermal reforming of acetic acid. Catalysts 2016, 6, 85. [CrossRef]

32. Buelens, L.C.; Galvita, V.V.; Poelman, H.; Detavernier, C.; Marin, G.B. Super-dry reforming of methane intensifies $\mathrm{CO}_{2}$ utilization via Le Chatelier's principle. Science 2016, 354, 449-452. [CrossRef] [PubMed]

33. Dou, B.; Jiang, B.; Song, Y.; Zhang, C.; Wang, C.; Chen, H.; Du, B.; Xu, Y. Enhanced hydrogen production by sorption-enhanced steam reforming from glycerol with in-situ $\mathrm{CO}_{2}$ removal in a fixed-bed reactor. Fuel 2016, 166, 340-346. [CrossRef]

34. Rydén, M.; Ramos, P. $\mathrm{H}_{2}$ production with $\mathrm{CO}_{2}$ capture by sorption enhanced chemical-looping reforming using $\mathrm{NiO}$ as oxygen carrier and $\mathrm{CaO}$ as $\mathrm{CO}_{2}$ sorbent. Fuel Process. Technol. 2012, 96, 27-36. [CrossRef]

35. Hafizi, A.; Rahimpour, M.R.; Hassanajili, S. Hydrogen production via chemical looping steam methane reforming process: Effect of cerium and calcium promoters on the performance of $\mathrm{Fe}_{2} \mathrm{O}_{3} / \mathrm{Al}_{2} \mathrm{O}_{3}$ oxygen carrier. Appl. Energy 2016, 165, 685-694. [CrossRef] 
36. Tang, M.; Xu, L.; Fan, M. Progress in oxygen carrier development of methane-based chemical-looping reforming: A review. Appl. Energy 2015, 151, 143-156. [CrossRef]

37. Meshksar, M.; Daneshmand-Jahromi, S.; Rahimpour, M.R. Synthesis and characterization of cerium promoted $\mathrm{Ni} / \mathrm{SBA}-16$ oxygen carrier in cyclic chemical looping steam methane reforming. J. Taiwan Inst. Chem. Eng. 2017. [CrossRef]

38. Dou, B.; Song, Y.; Wang, C.; Chen, H.; Yang, M.; Xu, Y. Hydrogen production by enhanced-sorption chemical looping steam reforming of glycerol in moving-bed reactors. Appl. Energy 2014, 130, 342-349. [CrossRef]

39. Köpfle, N.; Mayr, L.; Schmidmair, D.; Bernardi, J.; Knop-Gericke, A.; Hävecker, M.; Klötzer, B.; Penner, S. A comparative discussion of the catalytic activity and $\mathrm{CO}_{2}$-selectivity of $\mathrm{Cu}-\mathrm{Zr}$ and $\mathrm{Pd}-\mathrm{Zr}$ (intermetallic) compounds in methanol steam reforming. Catalysts 2017, 7, 53. [CrossRef]

40. Yang, X.; Wang, Y.; Wang, Y. Significantly improved catalytic performance of Ni-based MgO catalyst in steam reforming of phenol by inducing mesostructure. Catalysts 2015, 5, 1721-1736. [CrossRef]

41. Abad, A.; Adánez-Rubio, I.; Gayán, P.; García-Labiano, F.; de Diego, L.F.; Adánez, J. Demonstration of chemical-looping with oxygen uncoupling (CLOU) process in a $1.5 \mathrm{~kW}_{\text {th }}$ continuously operating unit using a Cu-based oxygen-carrier. Int. J. Greenh. Gas Control 2012, 6, 189-200. [CrossRef]

42. Ayodele, B.V.; Khan, M.R.; Cheng, C.K. Syngas production from $\mathrm{CO}_{2}$ reforming of methane over ceria supported cobalt catalyst: Effects of reactants partial pressure. J. Nat. Gas Sci. Eng. 2015, 27, 1016-1023. [CrossRef]

43. Ramírez-Hernández, G.Y.; Viveros-García, T.; Fuentes-Ramírez, R.; Galindo-Esquivel, I.R. Promoting behavior of yttrium over nickel supported on alumina-yttria catalysts in the ethanol steam reforming reaction. Int. J. Hydrogen Energy 2016, 41, 9332-9343. [CrossRef]

44. Li, J.; Xia, C.; Au, C.; Liu, B. $\mathrm{Y}_{2} \mathrm{O}_{3}$-promoted NiO/SBA-15 catalysts highly active for $\mathrm{CO}_{2} / \mathrm{CH}_{4}$ reforming. Int. J. Hydrogen Energy 2014, 39, 10927-10940. [CrossRef]

45. Sangwichien, C.; Aranovich, G.L.; Donohue, M.D. Density functional theory predictions of adsorption isotherms with hysteresis loops. Colloids Surf. A 2002, 206, 313-320. [CrossRef]

46. Youn, M.H.; Seo, J.G.; Jung, J.C.; Park, S.; Song, I.K. Hydrogen production by auto-thermal reforming of ethanol over nickel catalyst supported on mesoporous yttria-stabilized zirconia. Int. J. Hydrogen Energy 2009, 34, 5390-5397. [CrossRef]

47. Luo, L.; Songjun, L.; Zhu, Y. The effects of yttrium on the hydrogenation performance and surface properties of a ruthenium-supported catalyst. J. Serbian Chem. Soc. 2005, 70, 1419-1425. [CrossRef]

48. Li, B.; Zhang, S. Methane reforming with $\mathrm{CO}_{2}$ using nickel catalysts supported on yttria-doped sba-15 mesoporous materials via sol-gel process. Int. J. Hydrogen Energy 2013, 38, 14250-14260. [CrossRef]

49. Rydén, M.; Lyngfelt, A.; Mattisson, T. Synthesis gas generation by chemical-looping reforming in a continuously operating laboratory reactor. Fuel 2006, 85, 1631-1641. [CrossRef] 